\title{
The Relative Impact of Corporate Reputation on Consumer Choice: Beyond a Halo Effect
}

\author{
Associate Professor Paul F. Burke \\ UTS School of Business (Building 8) \\ University of Technology Sydney (UTS), \\ PO BOX 123 Broadway NSW 2007 Australia \\ Phone: +61 295143533 \\ paul.burke@uts.edu.au \\ Professor Grahame Dowling \\ University of Technology Sydney (UTS) \\ PO BOX 123 Broadway NSW 2007 Australia \\ Phone: +61 295144052 \\ grahame.dowling@uts.edu.au \\ Dr Edward Wei \\ University of Technology Sydney (UTS), \\ PO BOX 123 Broadway NSW 2007 Australia \\ Phone: +61 295143481 \\ edward.wei@uts.edu.au
}

\section{Biographical summary:}

Paul Burke is Associate Professor and ARC Research Fellow at the University of Technology Sydney. His work focuses on choice modelling and ethical consumption. He has published in the International Journal of Research in Marketing, Research Policy, Journal of Product Innovation \& Management, International Business Review, European Journal of Marketing, Journal of Business Ethics, Journal of Operations Management and Tourism Analysis.

Grahame Dowling is Professor at UTS School of Business. His research, relating to corporate reputation and marketing, has been published in Strategic Management Journal, MIT Sloan Management Review, Californian Management Review, European Management Review, Journal of Marketing and Journal of Consumer Research. His latest book is Winning the Reputation Game.

Edward Wei is a Senior Research Associate at UTS from which he received his PhD. He also holds a Masters of Business from QUT and a Bachelor of Economics from University of International Business \& Economics (UIBE), China. Edward has worked with various companies, including AC Nielsen, as a quantitative analyst, operations and survey manager. He has published in journals such as Design Science, Agenda, and Energy Policy.

\section{Acknowledgement and Financial Disclosure:}

The researchers acknowledge the assistance of colleagues and reviewers that have provided feedback and assistance, particularly Prof Marc Fischer and Dr Natalina Zlatevska. The research was supported by the Australian Research Council (DE130101463) and a UTS research grant. 


\title{
The Relative Impact of Corporate Reputation on Consumer Choice: Beyond a Halo Effect
}

\author{
Abstract \\ Previous work suggests that corporate reputation generates a 'halo effect' where products from \\ companies with better reputations are more likely to be chosen. We argue that corporate \\ reputation plays a more expansive role, proposing that consumers will be less price-sensitive to \\ offerings endorsed by companies with good reputations and that it moderates the marginal utility \\ of product features with high clarity. We also propose that an individual's knowledge of a \\ company increases the likelihood its products will be purchased. Using a choice model \\ incorporating an individual SEM-based reputation measure, we find support for these \\ hypothesised effects in the context of television choices. The results suggest that corporate \\ reputation warrants more attention by marketing managers to increase preferences for their \\ products through these mechanisms.
}

\section{Keywords:}

corporate branding; marketing management; corporate social responsibility (CSR), ethics; corporate reputation; consumer choice; marketing strategy; marketing management 


\section{Introduction}

Upon occasion, companies become embroiled in scandals and crises relating to various issues ranging from financial performance, questions of leadership, treatment of employees or impact of their operations on the natural environment. Some recent examples include: the Volkswagen emissions scandal; the convictions of the CEOs from WorldCom and Computer Associates for accounting and securities fraud; and, the exposure of organizational issues with respect to an alleged culture of sexism within Uber Technologies and Google. Alternatively, many companies undertake deliberate activities that shed a positive light on their operations. For example, this may include corporate social responsibility (CSR) activities such as those aimed at improving labour conditions or addressing environmental concerns in the supply chain or the sponsorship of a charitable event (Auger, Burke, Devinney, \& Louviere, 2003). Other companies may promote their reputation based on their competencies to enhance the evaluation of the overall product, such as the culture of innovativeness associated with companies like 3M (Gürhan-Canli \& Batra, 2004). These communications can occur through various mediums including shareholder reports, corporate advertising, media coverage, corporate websites, and consumer reports (Schlegelmilch \& Pollach, 2005). All such activities - whether negative or positive - affect the overall corporate reputation of the organization across all its stakeholder groups (Fombrun, 1996).

The issue of interest for marketing managers explored in this paper is the potential of a good or poor reputation to spill-over to a company's branded products as they are being evaluated by consumers. To date, some research suggests that there are cases in which consumers ignore reputation in their product choice deliberations (e.g., Boulstridge \& Carrigan, 2000; Page \& Fearn, 2005). However, the vast majority of scholars assume that consumers do factor the reputation of the company that stands behind or beside the product into their 
evaluations and choices (e.g., Auger et al., 2003; Dowling, 2016a; Fombrun, 1996; Gatti, Caruana, \& Snehota, 2012; Nguyen \& Leblanc, 2001; Srivoravilai, Melewar, Martin, \&Yannopoulou, 2011; Walsh, Mitchell, Jackson, \& Beatty, 2009). The aim of this research is to evaluate whether consumer choices are influenced by the reputation of the company that uses its name to brand products. We explore various pathways by which this occurs.

The research aims to make substantive and methodological contributions to the reputation and branding literatures which allow us to offer several strategic insights. First, the research investigates the relative impact of corporate reputation in influencing how consumers choose among a number of competing products. As such, it differs from previous research that has evaluated the impact of corporate reputation on the purchase intentions relating to one product (e.g., Nguyen \& Leblanc, 2001) or one organization only (e.g., Walsh et al., 2009). By focusing on consumer choices, it also differs from research that has focused on non-choice outcomes, such as attitudes, trust and identification (e.g. Du, Bhattacharya, \& Sen, 2007; Keh \& Xie, 2009); or other behaviours such as increased word-of-mouth (e.g., Lacey \& Kennett-Hensel, 2010; Walsh et al., 2009). Our research design allows us to see the impact of changes in corporate reputation on consumer choice outcomes relative to the impact that changes in a product's features have (unlike, for example, Arikan, Kantur, Maden, \& Telci, 2016). The methodology provides the first link between latent performance measures of corporate reputation based on reflective rating scales (e.g. Walsh et al., 2009) and multi-attribute accounts of product decision making using choice models (e.g., Auger et al., 2003; De Pelsmacker, Driesen, \& Rayp, 2005). Second, we account for individual differences in the valuation of a company's reputation, rather than examine such effects at an aggregate level or by making comparisons across experimental conditions. This addresses concerns about aggregation bias in evaluating the impact of corporate 
reputation on choices (Hutchinson, Kamakura, \& Lynch, 2000). Third, we examine reputation in relation to existing organizations rather than the evaluation of hypothetical or unlabelled alternatives (e.g., Auger et al., 2003; Mohr \& Webb, 2005). Fourth, we explore whether corporate reputation is simply a mechanism that affects the propensity to choose a product (a generic halo effect) or whether the effect is multi-faceted. In particular, we examine whether corporate reputation affects price sensitivity and moderates the preference for product features.

To preview the findings, we find support for the general halo effect that corporate reputation activities can influence product choices by improving the utility of a product offered by the company. We also find that individual level corporate reputation evaluations spill-over in a number of ways to reduce (increase) price-sensitivity and increase (decrease) the preference for longer warranties when offered by companies with good (poor) reputations. As such, the research speaks to marketing managers by indicating new strategies whereby corporate reputation can be leveraged across product features rather than be treated simply as a halo effect. Indeed, we find the impact of corporate reputation on choice is substantial relative to the competitive advantage offered by variation in product features. However, we find no evidence that consumers' preference for products that offer features that are poorly understood regarding their benefit can be somehow improved when offered by companies with better reputations.

The paper proceeds as follows. To establish the background theoretical context, we briefly review the nature of corporate reputation, corporate branding, and how corporate reputations have been found to impact consumer behaviour. We then present a model of how corporate reputation affects consumers' choices about a company's product offerings against those of their competitors. We describe a choice-based method to measure how much of an impact corporate reputation has on product choices as well as how much it moderates the impact of variation in 
product features on consumers' choices.

\section{Corporate Reputation and Product Branding}

In the field of strategy the notion of corporate reputation is well developed (e.g., Barnett \& Pollock, 2012). Here economists and management scholars have studied the conditions under which the reputation of a company is used by its multiple stakeholders to help them make decisions about whether or not to engage with it (e.g., Devinney, Dowling, \& PermAjchariyawong, 2008; Espeland \& Sauder, 2007; Roper \& Davies, 2007). One example that is familiar to most readers of this journal is the market for MBA programs. These are typically branded or co-branded with the name of the parent university. Here we see senior university administrators, deans, faculty, students, and alumni taking a keen interest in the reputation of their school because it acts as a measure of past performance, a signal of inherent quality, and an attractive attribute to faculty and students. Of particular interest is the role that a good reputation plays in influencing student (consumer) choice. For example, it can attract more students; help decrease their sensitivity to higher fees, and improve perceptions about the quality of faculty and facilities. The first effect is broad in nature, like a halo effect; the second effect focuses on price sensitivity, and the third effect focuses on how preference for a particular product feature can be moderated by the nature of a good (or bad) reputation. In this paper, we explore the ability of a good reputation to produce all these effects in the context of consumer choices.

Because the concept of corporate reputation has been studied from various academic discipline and stakeholder perspectives there are many (similar) definitions in use. The overlap with other terms, such as corporate brand, corporate image, and corporate identity further adds to confusion about the precise meaning of the construct (Balmer, 2001; Gatti et al., 2012). 
Notwithstanding this diversity, Dowling's (2016b) review of the construct suggests that the most common interpretation is that a corporate reputation is an individual's overall evaluation of a company. Some suggest that this is similar to that of an attitude (e.g., Caruana, Cohen, \& Krentler, 2006). This evaluation is based on the company's key attributes, performance and behaviour. A good reputation acts as a signal of quality and a performance bond to internal stakeholders such as employees and external stakeholders such as customers. Because companies are expected to live up to their reputations they generally endeavour to maintain or enhance stakeholder evaluations.

From a strategic perspective, corporate reputation, therefore, has many of the attributes of an intangible asset because it is difficult for rivals to imitate, acquire or substitute, and can offer opportunities to gain a competitive advantage (Rindova \& Martins, 2012). Accounting often evaluates corporate reputation in terms of an intangible asset and goodwill, whereas organizational behaviour can evaluate it in terms of perceptions among existing and potential employees and other internal stakeholders (Balmer, 1998).Whilst from economics, reputation is a signal of the quality of a company's behaviour and products (Allen, 1984; Shapiro, 1982, 1983). From a corporate perspective the concepts of branding, image, identity and reputation are used to reflect both how an organization seeks to project itself to its stakeholders (e.g., its desired brand position), and how it is perceived by these groups (e.g., its actual brand position). Different scholars thereby provide different interpretations of how these projections translate into perceptions and evaluations (e.g., Balmer, 2001; Balmer \& Gray, 2003; de Chernatony, 1999; Schultz, Hatch, \& Adams, 2012; Yu Xie \& Boggs, 2006).

In the discipline of marketing, corporate reputation can be viewed from the customer or end-users' perspective (Balmer, 1998) and is sometimes considered as similar to brand equity 
(Aaker, 2004; Erdem \& Swait, 1998; Kocak, Abimbola, \& Özer, 2007). Because the drivers of brand equity are similar to those of corporate reputation, namely, brand knowledge (Keller, 2003) and company knowledge, this is understandable. Such a view is consistent with corporate reputation being a holistic judgement made by consumers about a company's attributes, which evolves over time and is reinforced via communication and performance (Gary \& Balmer, 1998).

Our perspective is that corporate branding differs from product branding because of its strategic focus, namely, a) the company rather than the product is prominent; b) the corporate brand speaks to all stakeholders rather than just target consumers; and, c) corporate brands tend to be the responsibility of senior executives rather than brand managers (Balmer, 2001). Thus, since corporate brands reflect the values, capabilities, culture and actions of the entire corporation and its employees (Keller \& Richey, 2006) it presents many challenges with respect to resourcing, management, and obtaining cross-functional support (Balmer \& Gray, 2003; Yu Xie \& Boggs, 2006). This also means that the impact of corporate reputation activities can be visible across multiple unrelated product categories (Balmer, 2001). Our perspective also highlights that building a good corporate reputation is driven by a variety of organizational level activities, some of which involve mainstream marketing activities such as advertising, and some of which are beyond the control of marketing managers, such as media reporting (Yu Xie \& Boggs, 2006). As Keller and Lehmann (2006) suggest, these sets of activities interact.

Product branding thereby focuses on individual brands with respect to product quality, service, innovativeness of features, with a focus on current and prospective consumers. At a wider level, corporate branding focuses on attributes of the company that support its potentially broad range of products and services, with a broader consideration of stakeholders beyond consumers. As such, in some cases corporate reputation overlaps with aspects of brand 
reputation (Napoli, Dickinson-Delaporte, \& Beverland, 2016). In cases where a product carries the company name, these attributes can be a potent source of product utility alongside sources of utility derived from the product features themselves. As such, a key aspect of the branding strategy of a company is whether or not to link the company name to its products and services (Aaker \& Joachimsthaler, 2000). The present research examines, in relative terms, the utility that consumers derive from corporate reputation and product features, and whether the interaction between them further amplifies the utility of a product to alter consumer choices.

\section{The Impact of Corporate Reputation on Consumer Behaviour}

The primary mechanism that marketers use to link a company to its products is by the way that the corporate name is used in product and service names. For example, some products are branded under the company name (e.g., Head tennis racquets ; Sony televisions), while others combine the company and product names (e.g., 3M's Scotch tape; Nestlé Kit Kat), and others put the company name in small print on the label of the product (e.g., Head \& Shoulders shampoo made by Procter \& Gamble). Aaker (2004) has referred to the first two strategies as creating a 'branded house', an approach which aims to leverage positive associations about the company (Aaker \& Joachimsthaler, 2000). Here the company stands with the product or clearly beside it and if consumers know about the company its reputation may become a prominent attribute of the offering for target customers. In the last case, which Aaker calls a 'house of brands', rather than seek to link the product to the company the emphasis is to create brands with a stand-alone position or a strong value proposition. In the former case, the company behind the brand and its corporate reputation is an integral part of the product branding strategy and the value proposition for consumers; particularly when the organization's corporate brand is prominent (e.g., Fombrun, 
Gardberg, \& Sever, 2000; Gatti et al., 2012).

From a conventional brand perspective, corporate reputation is a potential secondary source of a consumer's brand knowledge (Keller, 2003) and may be triggered if the company's branding, communication or identity strategy highlights that the company stands behind or beside the product brand. When this happens, studies have suggested that consumers do factor into their deliberations the attributes of companies and their overall reputation. For example, Dawar and Parker (1994) found that consumers use the reputation of a retailer as a signal of product quality. Brown and Dacin (1997) found that the perceived ability and social responsibility of well-known companies influenced the consumers' beliefs and attitudes about the new products they manufactured. Nguyen and Leblanc (2001) found that corporate reputation affects customer loyalty. Gürhan-Canli and Batra (2004) used experiments to illustrate that a company's reputation for innovation and trustworthiness affects consumer evaluations for a product made by that company in a situation characterized by a high level of perceived risk. Klein and Dawar (2004) showed how a company's reputation for social responsibility affects consumers' attributions for blame in a product-harm crisis. Gatti et al. (2012) found that a good corporate reputation was correlated with a higher purchase intention for Italian Christmas cake. Helm (2013) showed that a good corporate reputation dampened customers’ potential negative reactions to price increases. In a series of experiments, Chernev and Blair (2015) showed that a reputation for social responsibility could influence consumer perceptions of the functional performance of the company's products. And Habel, Schons, Alavi, and Wieseke (2016) found that the perceptions of a company's social responsibility created mixed effects of the company's perceived price fairness.

Like many studies of consumer behaviour most empirical studies of corporate reputation 
use an attitude-behaviour approach to study how the perceived capabilities, character or practices of a company influences reaction to its actions, products and services. Fewer studies consider how corporate reputation influences a consumer's choice amongst directly competing products. That is, most work considers the role of corporate reputation in terms of just one corporation (e.g., Arikan et al., 2016; Nguyen \& Leblanc, 2001; Walsh et al., 2009) or in terms of its impact on non-behavioural outcomes such as trust (e.g., Du et al., 2007; Keh \& Xie, 2009) or word-ofmouth (e.g., Lacey \& Kennett-Hensel, 2010; Walsh et al., 2009), and without reference to how corporate reputation plays a role in consumer's decision making relative to product features they encounter in their choices.

One exception is work by Auger et al. (2003) who examined consumers’ willingness to pay for social product features. The social product features were described in terms of supplier manufacturing practices, such as not employing child labour or paying workers above the minimum wage. The choice experiments asked consumers to choose amongst products described using a combination of functional and social features. They found that the socially responsible practices used to enhance a company’s reputation were significant determinants of product choice. Whilst the study considered consumers' choice amongst competing offerings, the role of brands in each case was presented in terms of an overarching halo effect (via a brand-specific constant) where it was assumed a more preferred brand (e.g., Nike) had a higher propensity to be chosen than a less preferred brand (e.g., Reebok). From this study, it is not clear whether variation in the corporate reputation of these brands at an individual level had some capacity to alter choice, and whether preferences for the functional features of the product or sensitivity to the pricing of products offered by each brand were somehow dependent on these evaluations of reputation. To date, research involving choices where organizational-level activities (like CSR) 
or outcomes of such activities (namely, corporate reputation) has only considered general halo effects, such that brands with better reputations are more likely to be chosen.

As we will develop further in the next section, a good (or poor) reputation can enhance (decrease) the likelihood that a particular product will be chosen over competing products. The primary mechanism by which this can happen is a halo effect whereby the overall evaluation of the company influences evaluations of the product's features in a way that is consistent with this overall evaluation. When the quality of the features of the product or service are difficult to assess before consumption the reputation of the company may play a significant role in helping to reduce perceived risk (e.g., Gürhan-Canli \& Batra, 2004). We propose that understanding the relative impact of corporate reputation in the context of consumer choice requires a consideration of how consumers make trade-offs between brand names, product features, prices, and the reputation of the company behind this offering. Further, the way in which these elements interact also suggests several ways corporate reputation may enter consumers’ product valuations.

\section{Theoretical Framework and Development of Hypotheses \\ Overview of Consumer-Based Choice Model of Corporate Reputation}

Our research focuses on how the reputation of a company alters the utility of a product when it is being considered for purchase and thereby alters choice outcomes. Our research hypotheses shown in Figure 1 explicitly focus on the role of corporate reputation in the evaluation of competing products (i.e., judging the utility of each) and choice (i.e., via a process of utility maximization). In Figure 1, the latent utility is impacted by several components, and, consistent with most choice frameworks in marketing, we include a number of product-related factors, namely, brand, price and product features (e.g., Louviere, Hensher, \& Swait, 2000). In the 
present research, we further consider various hypotheses on how corporate reputation influences the utility of a product. By observing how choices are made among a number of competing products with various attributes and features, and under the assumption of utility maximization, we are able to formulate a probabilistic model of consumers decision making (Luce, 1959; McFadden, 1974, 1986; Thurstone, 1927) expanded to include corporate reputation.

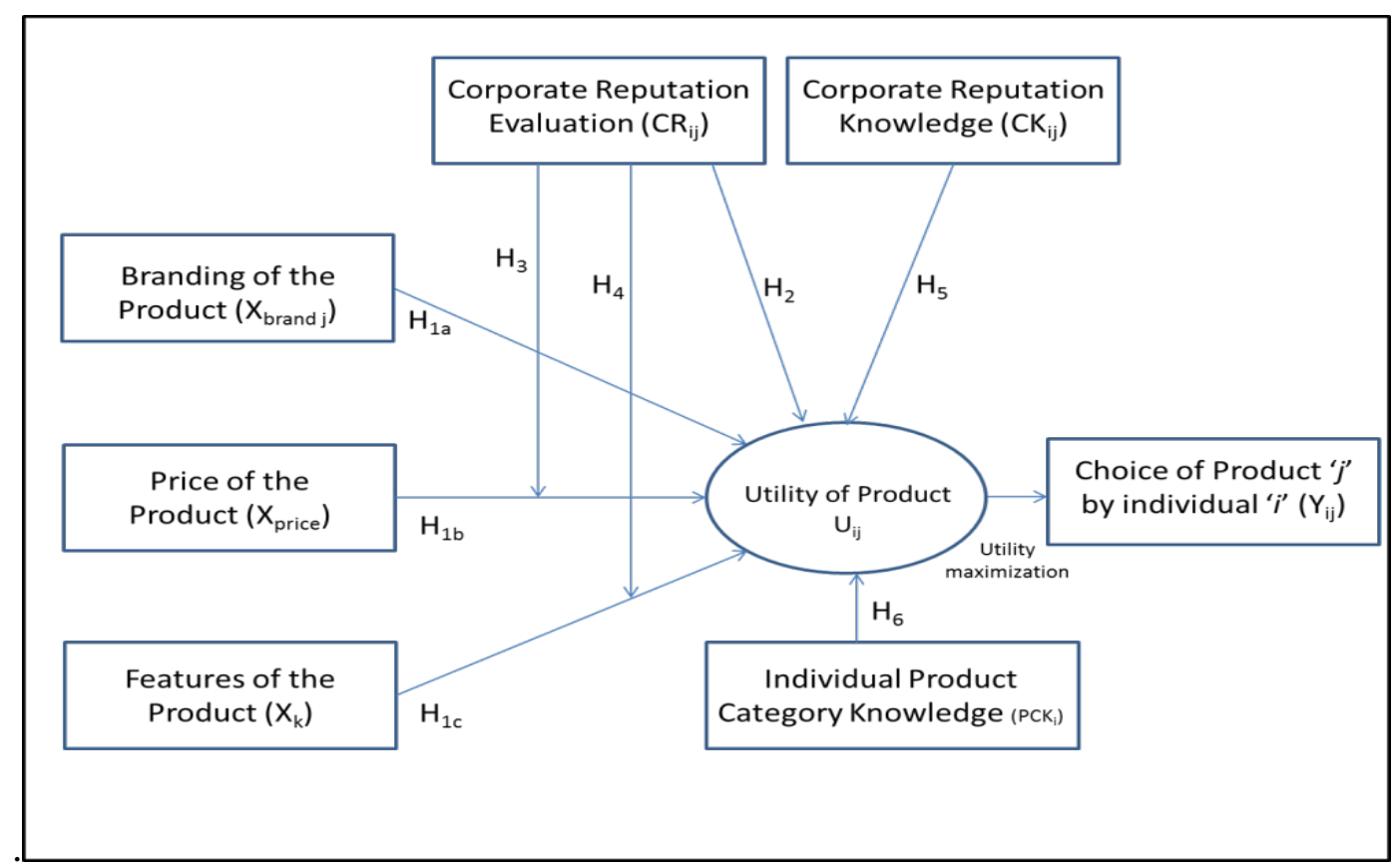

FIGURE 1: OVERVIEW OF MODEL AND HYPOTHESES

To provide an overview, the first hypothesis postulates that the utility of a product is determined by its attributes and brand name. The product with the highest utility will be the most preferred in a choice situation. The second hypothesis (halo effect of CR) partials out the corporate reputation effect from the brand name effect, similar to studies in marketing evaluating the impact of brand equity on choice (e.g., Erdem \& Swait, 1998). This shows how much of the overall brand effect is due to the reputation of the company whose name appears on the product. 
The third hypothesis (price effect of CR) focuses on the effect of a good corporate reputation on price sensitivity. The fourth hypothesis (attribute effect of CR) focuses on how corporate reputation affects the marginal utility relating to a specific product feature. Finally, we account for the impact that consumer's knowledge of the product category and knowledge of the company have on the utility of the product. We now discuss the background to each of these hypothesized effects in more detail

\section{Impact of Brands, Price and Features on Choice (Basic Product Choice Model)}

First, under the assumption of utility maximization, the model assumes that a consumer will choose the product that offers greater utility when considered against all others (Thurstone, 1927). As such, our work in the context of corporate reputation is distinct in terms of focusing on competing product choices rather than focusing on evaluation of a company overall in terms of its reputation (e.g., Walsh et al., 2009) or considering the overall likelihood of choosing an option without explicit comparison to another (e.g., Gatti et al., 2012). In this way, our random utility theory based framework is similar to the work of Auger et al. (2003) who adopted it in the context of studying the impact of ethical product features on consumers' choices, but instead we examine the impact of a company's reputation on consumers' choices.

As such, our first hypothesis focuses on the basic way in which models of utility maximization have been considered in marketing (e.g., Brazell et al., 2006; Burke, 2013; Erdem et al., 2002; Louviere et al., 2000; Louviere \& Woodworth, 1983; Swait, Erdem, Louviere, \& Dubelaar, 1993). That is, the utility of the product is determined by the characteristics or attributes which distinguish it from others, including its brand name, its price and product features. Under the assumption of utility maximization, consumers are assumed to choose the 
one product that provides maximum utility relative to all other competing products and to do so when this utility exceeds the utility associated with not choosing any of the alternatives under consideration (Luce, 1959; McFadden, 1974, 1986).

More formally, the model can be considered in terms of a random utility framework. The utility of product ' $\mathrm{j}$ ' can be broken into utility that can be captured or measured by the researcher (i.e., the systematic component of the utility function, $V_{j}$ ) and those that cannot (i.e., the random component, $\varepsilon_{j}$ ). The systematic component can then be described by a function of the attributes of the alternative and characteristics of the individual. Applying random utility theory, we observe that the $j^{\text {th }}$ alternative is chosen by individual ' $i$ ', iff $U_{j}>U_{q}$ for all $j \neq q$ under consideration. To link the expression of utility to the observable choice outcomes, $y_{i j}$, can be done by assuming the random component follows a suitable distribution (e.g., extreme value type 1; probit), giving rise to the unconditional choice probability (Ben-Akiva \& Lerman, 1985; Train, 2009):

$$
\operatorname{Pr}\left(y_{i j}=1\right)=\frac{\exp \left(V_{i j}\right)}{\sum_{q=1}^{J} \exp \left(V_{i q}\right)}
$$

Applied to the present research, we first consider that the latent utility of product ' $j$ ' $\left(U_{j}\right)$ is a function of its brand name $\left(\right.$ Brand $\left._{j}\right)$, its various product features $\left(X_{j}\right)$ and its price $\left(\right.$ Price $\left._{j}\right)$. The overall utility of an alternative is:

$$
U_{j}=V_{j}+\varepsilon_{j}=\alpha+\beta_{1} \text { Brand }_{j}+\beta_{2} X_{j}+\beta_{3} \text { Price }_{j}+\varepsilon_{j}
$$

Equation (2) is a base model that reflects the nature of the utility underlying choices that consumers make in everyday settings and in many choice experiments given to respondents. Our hypothesis is that respondents choose the best product based on a combination of brand, attributes and price. Thus, we expect $\beta_{1}, \beta_{2}$ and $\beta_{3}$ to be significant in 
the choice model. That is, we first hypothesize that consumers will place greater utility on products when offered by a more preferable brand (H1a), when offered at a lower price (H1b), and when offered with features that are more valuable than those that are not (H1c). We now develop the model further to consider how corporate reputation may affect the utility of an alternative and subsequent observable choice outcomes.

\section{Overarching Impact of Corporate Reputation (Halo Effect)}

The next component of the model considers how corporate reputation provides a general improvement in the evaluation of products when offered by a brand associated with a more reputable company. We hypothesize that products offered by companies with better reputations will generate greater utility in product evaluations, and hence, will be more likely to be chosen when considered against competing products. The hypothesis reflects the general belief that building better brands leads to better valuations among consumers (Walsh et al., 2009) and is consistent with the empirical work that has considered purchase intentions. For example, using a structural equation model of reputation and corporate social responsibility, Gatti et al. (2012) show that corporate reputation has a positive impact on purchase intentions, measured using two 7-point scale items relating to strength of intentions to select and purchase a brand of Panettone Christmas cake. Similarly, Mohr and Webb (2005) illustrated that intentions to purchase were higher for hypothetical companies undertaking corporate social responsibility activities. As such, we hypothesize that:

$\mathrm{H}_{2}$ : The utility of a product is higher for brands that are associated with companies that have better corporate reputations than their competitors.

With respect to our utility-based choice model, we consider this effect at an individual level via 
Corporate Reputation $\left(C R_{i j}\right)$, which is the reputation evaluation that individual ' $i$ ' holds of a particular company ' $j$ ' offering a product evaluated for purchase. This variable captures the halo effect noted earlier, but takes into account how this can vary across individuals. In essence, $\mathrm{H}_{2}$ differs from other studies by accounting for how corporate reputation is heterogeneous among consumers rather than evaluating its impact at an aggregate level only (Hutchinson et al., 2000). For example, Auger et al. (2003) captured the impact of Nike and Reebok on consumers' evaluations of shoes, but did not account for how these evaluations varied at the individual level or whether these aggregate evaluations were related to the corporate reputation of the two companies. As a result, Equation (3) becomes an improved model for predicting how consumers make choices than Equation 1 by recognizing that corporate reputation is an evaluation that can vary across consumers and thereby results in variation in the utility assigned to each product:

$$
U_{j}=\alpha+\beta_{1} \text { Brand }_{j}+\beta_{2} X_{j}+\beta_{3} \text { Price }_{j}+\beta_{4} C R_{i j}+\varepsilon_{i j}
$$

By considering product choices in a random utility framework, the impact of corporate reputation on product choices offers the opportunity to evaluate its effect against other product features on a comparable scale (i.e., utility). In other words, the model presents an opportunity to evaluate how much choices are altered by changes in individual perceptions of a company's corporate reputation against changes in the features of the product. By further translating these changes in utility to the equivalent changes in prices indicated by the price coefficient, comparisons can be made in willingness-to-pay terms. In a similar vein, Auger et al. (2003) demonstrated the usefulness of this random utility/choice modelling approach to show the willingness-to-pay that consumers placed on changes in the functional features of products (e.g., the durability of a shoe; whether a soap is round or square) against changes in the social features of a product (e.g., whether a shoe is produced using child labour; whether a soap is tested on 
animals). We do the same, but in terms of comparing the impact that changes in product features have on consumer choices against the impact that changes in individual-level evaluations of corporate reputation have on consumer choices.

\section{Impact of Corporate Reputation on Price Sensitivity (Price Effect)}

Whilst previous research suggests the overall utility of products is positively related to improvements in corporate reputation, other effects in consumer's evaluations may also be occurring and can be considered by the choice framework. For example, Creyer (1997) found that consumers reported a disposition to reward (punish) ethical behaviour via a willingness to pay higher (lower) prices for products offered by firms demonstrating (un)ethical behaviours. Erdem, Swait, and Louviere (2002) found that consumers were willing to pay more for products when offered by higher equity brands relative to lower equity brands. Also, Helm (2013) found that a good corporate reputation helps to dampen customers' potential negative reactions to a price increase. In turn, we hypothesize that companies that have better reputations will be able to command higher prices, whilst those with poorer reputations must accept that they must charge less for an equivalent product:

$\mathrm{H}_{3}$ : Consumers will be less (more) sensitive to the price of products that are made by a company with a better (poorer) corporate reputation.

In a choice model, this effect can be captured by a price coefficient that is moderated depending on the corporate reputation of the company behind the brand. As such, we can expand our model of latent utility to consider this moderating effect $\left(\right.$ Price $\left._{j} * C R_{i j}\right)$ :

$$
U_{j}=\alpha+\beta_{1} \text { Brand }_{j}+\beta_{2} X_{j}+\beta_{3} \text { Price }_{j}+\beta_{4} C R_{i j}+\beta_{5} \text { Price }_{j} * C R_{i j}+\varepsilon_{i j}
$$

In Equation (4), the price effect includes two components. First, the main effect (captured by $\beta_{3}$ ) relates changes in price to changes in utility; this captures the sensitivity of consumers to price as 
examined in Hypothesis 1b. Because most consumers will select a lower priced offering, all else being equal, we expect that $\beta_{3}<0$ and significant. The second component is the interaction effect of CR and price; the estimate of $\beta_{5}$ captures whether the sensitivity to changes in price is further moderated by variation in the corporate reputation of the company behind the offering. Given the preceding discussion and hypothesis, we predict that CR has a positive interaction on price, such that $\beta_{5}$ will be positive and statistically significant.

\section{Impact of Corporate Reputation on Product Features (Attribute Effect)}

The multi-attribute nature of the choice framework allows the opportunity to explore other effects in terms of how each product feature impacts product choice, as considered in H1c. However, the preference for such features may depend on which company offers the feature. In other words and in terms of the random utility framework, the marginal utility associated with each product feature may be moderated by the perceived corporate reputation of the company offering the feature.

Some previous literature suggests exploration of these effects in a number of areas. For example, prior research suggests that signals of quality are important in the context of warranties. For example, Boulding and Kirmani (1993), as well as Soberman (2003), argue that a longer warranty period is a signal from the company that they are confident that their products will last, thereby enticing consumers to infer a higher quality offering. As such, we expect consumers to prefer a warranty that is offered by a more reputable company than a less reputable company. In effect, a good reputation acts as a corporate performance bond (e.g., Dowling, 2016a). This assertion is consistent with other works that suggest that consumers seek and use a number of pre-purchase signals about the quality of the products being considered including price, physical appearance and reputation (Dawar \& Parker, 1994). This view is also consistent with a risk 
averse decision-making strategy, such as observed in Gürhan-Canli and Batra (2004) who used experiments to illustrate that a company’s reputation for innovation and trustworthiness affects consumer evaluations of a product made by that company in a situation characterized by a high level of perceived risk. In other words, positive reputations provide confidence in the face of uncertainty (Shapiro, 1982, 1983).

Similarly, prior research in the context of meaningless and ambiguous product features further suggests that reputation can play a valuable role to mitigate risky decisions and inference making. For example, Broniarczyk and Gershoff (2003) find that the preference for products with trivial features - those features that consumers see as distinct from competitors, but unclear about their benefit - is more pronounced when offered uniquely by a high equity brand, but diminish if the nature of the triviality is disclosed or offered by a low equity brand. The hypothesis is consistent with the notion that preferences are not necessarily precise and welldefined, but are often constructed on an ad-hoc basis dependent on the circumstances of the decision making context (or moment) in which consumers find themselves (March, 1978; McFadden, 1986). Similarly, Hsee (1996) finds that product features that are ambiguous in value (i.e., hard-to-evaluate) become easier-to-evaluate when presented alongside other options (i.e., joint-evaluation). As such, we argue that the marginal utility of a given product feature is further moderated by the corporate reputation of the firm standing behind the offering; however, the level of moderation is dependent on the clarity in value of the feature. Specifically, combing the findings of Hsee (1996) and Broniarczyk and Gershoff (2003) we hypothesise that the role of corporate reputation in supplementing the value placed on some product features diminishes in choice settings where several companies offer a similar product feature (as in many markets where product features are shared) and so the marginal utility of the ambiguous feature is 
diminished. Instead, we hypothesize that the impact of corporate reputation will be stronger in cases where the product features are clearer in their value to consumers and when offered by multiple competitors, by predicting that consumers will prefer the quality signalled by the more reputable company. As such, we hypothesise that:

$\mathrm{H}_{4}$ : The marginal utility of a product with features that consumers (do not) clearly understand will (not) be higher when offered by companies with better corporate reputations than their competitors.

Under this hypothesis, we predict that CR has a moderating effect on the marginal utility offered by some product attributes, such that $\beta_{6}$ is positive in the following:

$$
U_{j}=\alpha+\beta_{1} \text { Brand }_{j}+\beta_{2} X_{j}+\beta_{3} \text { Price }_{j}+\beta_{4} C R_{i j}+\beta_{5} \text { Price }_{j} * C R_{i j}+\beta_{6} X_{j} C_{C R_{i j}}+\varepsilon_{i j}
$$

We suggest that the impact of perceived reputation of a company in moderating the marginal utility of product features will only apply to those that consumers clearly understand and that are considered to be functionally important. If a product feature is difficult to understand and thus is likely to be unimportant then the reputation of the company will not be potent enough to make it important (c.f., Carpenter, Glazer, \& Nakamoto, 1994).

\section{Impact of Knowledge on Product Choices}

The final effects relate to variables accounting for differences in knowledge about the product category and the reputation of companies operating in the category. In general, most models of decision making indicate that more information or knowledge reduces the risk and uncertainty of judgements being made (Ratchford, 2001). As such, those consumers with more knowledge about a product category are in a position to more confidently evaluate alternatives, select and purchase a chosen offering rather than defer their product choice (Dhar, 1997). Similarly, better insights into the corporate reputation of a company can offer consumers a means to strengthen 
their evaluations and reduce any need to delay following through with their product choice. This is consistent with one of the previously noted roles of a good corporate reputation in that in can act as a source of uncertainty reduction and confidence for consumers thereby reassuring them that the company that made the product will meet the expectations created by its marketing communications (Du et al., 2007; Keh \& Xie, 2009; Ponzi, Fombrun, \& Gardberg, 2011). From another perspective, Fombrun and van Riel (2004) suggest that salience is a primary driver of corporate reputation. Here, company 'fame' leads to company 'fortune'. That is, the best known companies are the ones that have the best reputations and, in turn, this provides a competitive advantage. Under both arguments, we therefore predict:

$\mathrm{H}_{5}$ : The utility of a product will be higher when a consumer has a greater knowledge about the corporate reputation of the company offering the product.

$\mathrm{H}_{6}$ : Consumers with greater knowledge about a product category will have higher intentions to purchase.

Under these hypothesized effects, the utility of an individual offering is therefore positively impacted by individual knowledge about the company behind the offering $\left(C R K_{i j}\right)$ and the knowledge of the individual about the product category $\left(P C K_{i}\right)$. Incorporating these two knowledge-related variables into our model of overall product utility expands to the following: (6) $U_{j}=\alpha+\beta_{1}$ Brand $_{j}+\beta_{2} X_{j}+\beta_{3}$ Price $_{j}+\beta_{4} C R_{i j}+\beta_{5}$ Price $_{j * C} C R_{i j}+\beta_{6} X_{j * C} C R_{i j}+\beta_{7} C R K_{i j}+\beta_{8} P C K_{i}+\varepsilon_{i j}$

It is worth noting that under this equation, the impact of product category knowledge enhances the utility of all options under consideration (hence, the absence of the subscript ' $j$ ' in $\left.P C K_{i}\right)$. As such, the overall utility of all options is raised against the no-choice option with utility set to zero for identification purposes. This translates to a higher propensity to purchase as hypothesized under $\mathrm{H}_{6}$ and subsequent prediction that $\beta_{8}$ will be positive and significant. In 
contrast, under $\mathrm{H}_{5}$ the knowledge is particular to a given alternative (hence, the presence of the subscript ' $j$ ' in the measure $C R K_{i j}$ ). In this regard, the utility is expected to be different for each alternative in a given choice set based on knowledge about the brand, and subsequently we predict that $\beta_{7}$ will be positive and significant.

In summary, this final model considers how corporate reputation affects the utility of the products that they offer against other competitors. It allows these effects to be considered in relative terms, such that it can be used to assess whether changes in the impact of corporate reputation on utility are just as relevant against changes in the functional features of the product in terms of altering consumer choices. Our model suggests multiple pathways for this impact of corporate reputation on choice to occur, namely: a) via a general halo effect; b) by altering the marginal utility of some product features; and, c) by altering price sensitivity. These effects are further considered in terms of the knowledge of a consumer. We now discuss the methodology that was used to test these hypothesized effects.

\section{Methodology}

We first conducted a preliminary study to select a set of brands and product features, and to test the validity of our principal measure of corporate reputation. We then used an experimental choice-based methodology to test our hypotheses. We conducted the test of the hypothesized effects in the context of television choices. This category was anticipated to be a reasonably involved purchase such that the impact of price, product features and corporate reputation would require deliberation relative to choices where more habitual decision-making may occur. Also, televisions are tangible, heterogeneous products that are familiar to most people. Thus, unlike something like electricity where it is the company rather than the product that provides the major 
source of differentiation (see Walsh, Dinnie, \& Wiedmann, 2006), televisions can be evaluated on the basis of their features and/or the company that makes them. Also, televisions provided the opportunity to identify a reasonable set of product features that varied with respect to clarity in order to test $\mathrm{H}_{4}$.

Pre-test

An extensive search of retailer websites was used to identify a list of 21 available corporate brand named televisions and a list of 22 features that described these televisions. We then interviewed 116 people selected from a commercial consumer panel who were screened as being reasonably knowledgeable about televisions. We asked respondents about their awareness of each brand by asking them to select (via a tick box) those manufacturers that they had heard of. We also asked them about which companies that produced these brands had the best and worst reputations out of a total of 21 brands, as well as rating each on a scale of 1 (very poor) to 10 (very good) with respect to their overall corporate reputation. From these results, we selected three well-known brands to be used in the main choice study, namely, Sony, Panasonic and Toshiba. The choice to use three Japanese companies also avoided any confound associated with country-of-origin effects. The profile of these brands is shown in Table 1.

We also measured the corporate reputation of the two companies that respondents nominated as having the best and worst reputation from the set of brands that they had heard of. The measure of corporate reputation was the Reputation Quotient (RQ) (see, Fombrun et al., 2000). This 20-item measure is composed of six underlying constructs, namely: 1) emotional appeal; 2) innovativeness and quality of products; 3) vision and leadership; 4) workplace environment; 5) social and environmental responsibility; and, 6) financial performance. Each respondent rated how much they agreed or disagreed with various statements reflective of these 
constructs on a scale on a 7-point scale (1=totally disagree; $7=$ totally agree). From these responses we used confirmatory factor analysis and structural equation modelling to confirm that the structure of this RQ measure aligned with prior works (e.g., Agarwal, Osiyevskyy, \& Feldman, 2015; Fombrun \& van Riel, 2004). Details of the measure and analysis are provided in Appendix 1. These measures were then adopted for use in the main study.

We also asked respondents to rate each of the 22 product features on clarity and importance. Importance was measured on a 7-point scale with respondents asked how much they consider a feature when purchasing a new television (1=not important; 7=very important). Clarity was measured on a 7-point scale with respondents asked to indicate how much they understood each feature (1=not clear at all; 7=very clear). Based on their responses, we selected 11 features that ranged from low to high in importance and in clarity (see Table 2). These features were categorized into three groups, namely, (1) highly important and high in clarity price, warranty and screen size, (2) moderately important and moderately high in clarity - wall mounting, super slim, number of USB ports, and personal video recorder (PVR), (3) moderately important, but low in clarity - 24P cinema, DTS (input-output), backlight control, and dynamic range control. There were no features that were identified as highly important but concurrently low in clarity. As explained below, these features were used to design the main experiment. 
Table 1: EVALUATION OF TELEVISION BRANDS USED IN MAIN STUDY

\begin{tabular}{lcccc}
\hline \multirow{2}{*}{$\begin{array}{c}\text { Awareness of } \\
\text { Company (\%) }\end{array}$} & $\begin{array}{c}\text { Ranked Best } \\
\text { (\%) }\end{array}$ & $\begin{array}{c}\text { Ranked Worst } \\
\text { (\%) }\end{array}$ & $\begin{array}{c}\text { CR } \\
\text { Rating }\end{array}$ \\
\hline Sony & 92.2 & 25.9 & 2.6 & $7.15^{\wedge}(1.81)$ \\
Panasonic & 96.6 & 12.1 & 0.0 & $6.78(1.76)$ \\
Toshiba & 80.2 & 1.7 & 4.3 & $6.17(1.80)$ \\
\hline
\end{tabular}

$\%$ refers to proportion of pilot sample ( $\mathrm{n}=116)$;

$\wedge$ refers to mean rating; standard deviation shown in parentheses

Table 2: EVALUATION OF TELEVISION FEATURES USED IN MAIN STUDY

\begin{tabular}{lccccccc}
\hline Product Feature & \multicolumn{3}{c}{ Importance } & \multicolumn{3}{c}{ Clarity } \\
\hline High Importance / High Clarity & $\mathbf{M}$ & SD & $\mathbf{9 5 \% ~ C I ~}$ & M & SD & 95\% CI \\
Price of television & 6.04 & 1.18 & $(5.83,6.26)$ & 5.85 & 1.42 & $(5.59,6.11)$ \\
Size of television (inches) & 5.93 & 1.15 & $(5.72,6.14)$ & 5.74 & 1.45 & $(5.47,6.01)$ \\
Warranty & 5.86 & 1.25 & $(5.63,6.09)$ & 5.72 & 1.53 & $(5.43,6.00)$ \\
& & & & & & \\
Moderate Importance / Moderate Clarity & M & SD & $\mathbf{9 5 \% ~ C I ~}$ & M & SD & $\mathbf{9 5 \% ~ C I ~}$ \\
Slim super slim television design & 4.90 & 1.42 & $(4.64,5.16)$ & 5.36 & $1.56(5.08,5.65)$ \\
Personal Video Recorder (PVR) & 4.61 & 1.82 & $(4.45,5.12)$ & 5.16 & 1.62 & $(4.86,5.45)$ \\
Number of USB ports & 4.71 & 1.67 & $(4.40,5.01)$ & 5.28 & 1.67 & $(4.98,5.59)$ \\
Wall mountable & 4.78 & 1.85 & $(4.27,4.95)$ & 5.50 & 1.65 & $(5.20,5.80)$ \\
& & & & & & \\
Moderate Importance / Low Clarity & $\mathbf{M}$ & SD & $\mathbf{9 5 \%}$ CI & M & SD & $\mathbf{9 5 \% ~ C I ~}$ \\
Dynamic Range Control & 4.70 & 1.50 & $(4.42,4.98)$ & 4.24 & 1.98 & $(3.88,4.61)$ \\
Backlight Control & 4.64 & 1.66 & $(4.33,4.94)$ & 4.22 & 2.04 & $(3.84,4.59)$ \\
DTS 2.0+Digital Out & 4.39 & 1.64 & $(4.09,4.69)$ & 4.05 & 2.03 & $(3.68,4.42)$ \\
24P True Cinema & 4.32 & 1.69 & $(4.01,4.63)$ & 3.93 & 1.95 & $(3.57,4.29)$ \\
\hline
\end{tabular}

$\mathrm{M}=$ mean rating; $\mathrm{SD}=$ standard deviation; $\mathrm{CI}=95 \%$ confidence interval; $\mathrm{n}=116$ 


\section{Overview of Main Study}

The main study involved several components including: a) a rating task to measure the corporate reputation of three companies as per the pre-test (Appendix 1); b) knowledge measures regarding

each company and the product category; c) a choice experiment to measure the relative impact of corporate reputation of products offered by these companies alongside their product features; and, d) manipulation checks relating to the clarity of the product features. The ratings tasks provided data to construct our corporate reputation measure; a latent, unobservable construct that varied for each individual and each company. The individual corporate reputation measures were then incorporated into the choice model to determine how much of the brand name effect due to the corporate reputation drives product selection relative to other attributions triggered by the product. To do this we created a set of experimentally designed choice tasks that included brand name, price, and a set of other product features. Experimentally designed choice tasks are a wellestablished method for quantifying how consumers make trade-offs across these when evaluating competing products (Louviere et al., 2000). We now describe the details of this choice experiment in more detail.

\section{Choice Experiment}

The choice experiment task showed each respondent four television options at a time. Eight such tasks completed in total (see Figure 2). Each television was described by a number of features including: brand (Sony, Panasonic or Toshiba), price (a uniform random value between \$1,499 and \$1,999), warranty (1 or 3 years) and screen size (50 or 55 inch). As noted earlier, in our pretest these features were found to be highly important and associated with a high level of clarity. Televisions were also described by a set of moderately important features that varied with respect to being low or high clarity, and each television was presented as having two out of eight 
possible features using a completely randomized design. The moderately important features with high clarity included whether a television: a) was wall mountable; b) was of super slim design; c) had a large number of USB ports; and d) had a personal TV/video-recorder (PVR) feature.

Likewise the moderately important attributes with low clarity were: a) 24 true cinema; b) DTS 2.0 + Digital output; c) backlight control; and d) Dynamic Range Control. Each television was also described by a set of fixed features, namely, each television was described as being an LEDLCD television, with FHD and a HD tuner at a refresh rate of $100 \mathrm{~Hz}$. The pre-test research of the television market suggested that these fixed specifications defined a television set that ranged in size from 50 to 55 inches and was priced between \$1,500 and \$2,000 as manipulated above.

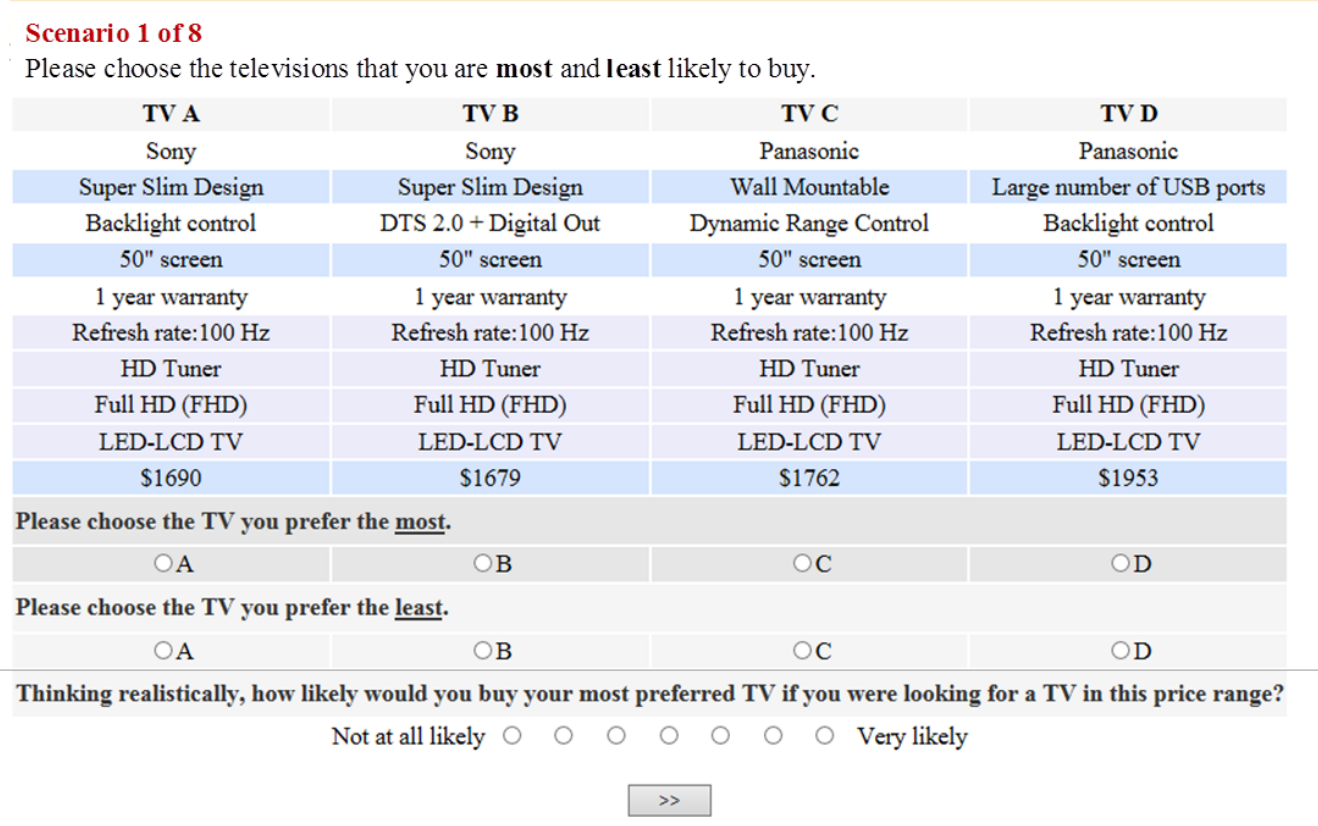

\section{FIGURE 2: Example of a Choice Scenario}


Each respondent completed eight choice tasks. In each choice task, we asked respondents to nominate their most and least preferred television from four options labelled A, B, C and D, and to indicate how likely they were to purchase their preferred option. The same brand was used in options A and B and another single brand in options $\mathrm{C}$ and $\mathrm{D}$. As such, this design allowed us to avoid observing choice behaviour based solely on the strong preference among respondents for one brand over another. For example, even if a respondent strongly preferred Sony they still had to consider which Sony option to choose based on the other product features.

\section{Data Collection}

For our main study we used an online panel from the global company GMI Lightspeed to survey 420 people over 18 years of age and who regularly watched television at home on a television set. We quota controlled age and gender so that our respondents were representative of the Australian population. The median response time to complete the questionnaire was 14 minutes. We identified 25 respondents that rushed through the data collection task and subsequently did not discriminate amongst the companies or the product choices; this group was removed from the analysis, resulting in a final sample of 395 respondents. Simulations of the model performed prior to data collection indicated this sample size would still be more than adequate given the nature of the experimental design balanced against the number of responses provided by respondents (Johnson \& Orme, 2003; Rose \& Bliemer, 2013). Such demands on sample size were smaller relative to other studies as the model included information provided about the most and least preferred options rather than the most preferred option only (Louviere, 2013).

\section{Analysis \& Results}

Corporate Reputation Measure and Manipulation Checks 
The primary variable of interest in Equations (3) to (6) is $C R_{i j}$, which captures how each individual evaluates each corporation with respect to its reputation. Appendix 1 presents the instrument validation from both the pilot $(\mathrm{n}=116)$ and the full experiment $(\mathrm{n}=395)$. Respondents also nominated which company had the best and the worst corporate reputation, described as their admiration and respect for the company that made television sets. In the main experiment, Sony was nominated in the majority of cases as having the best reputation (58\% of respondents), followed by Panasonic (34\%), and Toshiba (8\%). Likewise, respondents were least likely to nominate Sony as having the worst reputation (16\%) as compared to Panasonic (25\%) or Toshiba (60\%).

Fombrun and van Riel's (2004) salience based model of reputation noted earlier suggests that respondents would be most knowledgeable about Sony and least knowledgeable about Toshiba. After evaluating each company on each of the $20 \mathrm{RQ}$ characteristics of reputation, we asked respondents to rate their overall knowledge of these characteristics for each company on a 10-point scale from "no knowledge" to "extremely knowledgeable”. The average level of knowledge for each company was consistent with the pre-test results, with respondents being moderately knowledgeable about all companies, but significantly more knowledgeable of Sony $\left(\mathrm{M}_{\text {sony }}=5.84 ; \mathrm{SD}=2.33\right)$ and Panasonic $\left(\mathrm{M}_{\text {Panasonic }}=5.5 ; \mathrm{SD}=2.27\right)$, and being least knowledgeable of Toshiba $\left(\mathrm{M}_{\text {Toshiba }}=4.9 ; \mathrm{SD}=2.34\right)$. Differences in knowledge of each pair of companies were all significantly different $(p<.01)$. We also confirmed that the moderate and low clarity features found in the pilot occurred in the main experiment. The results were that these sets of features were significantly different in clarity $(p<.001)$, with a mean clarity rating of $\mathrm{M}=4.11(\mathrm{SD}=1.85)$ and $\mathrm{M}=5.50(\mathrm{SD}=1.57)$ for low and moderate clarity, respectively. 


\section{Model Estimation}

We used a conditional logit model (McFadden, 1974) to model respondents’ preferred television. The product features, a brand constant, a propensity to buy constant, and respondents' individual evaluations of the reputation of the companies were used as predictors of their choices. The resulting parameter estimates indicate the changes in utility that occur when a product feature is introduced relative to when it is not and whether such changes significantly alter predicted choice probabilities (see Table 3). Our results suggest that product features that are important and easier to understand (have greater clarity) are more likely to affect preferences for televisions, whilst, as expected - lower prices are preferable. Model fit statistics in the form of approximate R-squares are consistent with the lower fits observed in cases involving crosssectional data and a discrete multinomial outcome relative to those with a continuous dependent variable (Louviere et al., 2000, pp. 54-55).

\section{Hypothesis Tests}

Equation (2) is the base model for the choice experiments used in this study. It hypothesizes that the utility of a television is co-determined by its brand (H1a), price (H1b) and product attributes (H1c). In Table 3, the coefficients for each brand are significant and signs consistent with the pre-test results with Sony products being the most preferred whilst Toshiba is not as well regarded as the other two companies as a manufacturer of televisions; this provides support for H1a. The coefficient for price is negative and significant indicating respondents prefer products that are lower in price to those higher in price and thereby providing support for H1b. Also in Table 3, the marginal utility associated with most of the product features are significant (with the exception of being wall mountable and having digital output) and with the expected sign as per H1c. These results support Hypothesis 1. 
Table 3. COMPETING MODELS OF TELEVISION CHOICES

\begin{tabular}{|c|c|c|c|c|c|c|}
\hline & \multicolumn{3}{|c|}{$\begin{array}{c}\text { Model } 1 \text { (without CR) } \\
\text { (H1a-H1c) }\end{array}$} & \multicolumn{3}{|c|}{$\begin{array}{l}\text { Model } 2 \text { (with CR) } \\
\text { (H2-H6) }\end{array}$} \\
\hline & Est. $\beta$ & Est./se & & Est. $\beta$ & Est./se & \\
\hline \multicolumn{7}{|l|}{ Constant } \\
\hline Propensity to buy constant $(\alpha)$ & $.01(.07)$ & .10 & & $.08(.08)$ & 1.10 & \\
\hline \multicolumn{7}{|l|}{ Brands $\left(\beta_{1}\right)$} \\
\hline Sony & $.23(.02)$ & 12.96 & $* * *$ & $.06(.02)$ & 3.23 & *** \\
\hline Panasonic & $.10(.02)$ & 5.82 & $* * *$ & $.07(.02)$ & 3.76 & $* * *$ \\
\hline Toshiba^ & $-.34(.02)$ & -18.07 & $* * *$ & $-.13(.02)$ & -6.51 & $* * *$ \\
\hline \multicolumn{7}{|l|}{ Attributes with low clarity $\left(\beta_{2}\right)$} \\
\hline $24 \mathrm{P}$ true cinema & $.05(.02)$ & 2.45 & $* *$ & $.05(.02)$ & 2.47 & $* *$ \\
\hline DTS 2.0+Digital out & $.02(.02)$ & 0.88 & & $.02(.02)$ & 0.77 & \\
\hline Backlight control & $.00(-)$ & - & & $.00(-)$ & - & \\
\hline Dynamic range control & $.04(.02)$ & 2.25 & ** & $.05(.02)$ & 2.59 & ** \\
\hline \multicolumn{7}{|l|}{ Attributes with moderate clarity $\left(\beta_{2}\right)$} \\
\hline Wall mountable & $-.02(.02)$ & -0.98 & & $-.02(.02)$ & -1.10 & \\
\hline Super slim design & $.09(.02)$ & 4.68 & **** & $.09(.02)$ & 4.51 & *** \\
\hline Large number of USB ports & $.08(.02)$ & 4.15 & $* * *$ & $.07(.02)$ & 3.91 & $* * *$ \\
\hline PVR - Personal TV/Video Recorder & $.11(.02)$ & 6.04 & $* * *$ & $.12(.02)$ & 6.34 & $* * *$ \\
\hline \multicolumn{7}{|l|}{ Attributes with high clarity $\left(\beta_{2}\right)$} \\
\hline 55" Screen Size (vs. 50") & $.18(.01)$ & 14.22 & $* * *$ & $.19(.01)$ & 14.49 & $* * *$ \\
\hline 3 year warranty (vs. 1 year) & $.30(.01)$ & 23.57 & $* * *$ & $.32(.01)$ & 24.02 & $* * *$ \\
\hline Price (in $\$ 100$, mean centred) $\left(\beta_{3}\right)$ & $-.25(.01)$ & -27.60 & $* * *$ & $-.25(.01)$ & -27.71 & $* * *$ \\
\hline \multicolumn{7}{|l|}{ Corporate Reputation (CR) } \\
\hline Individual Evaluation of CR $\left(\beta_{4}\right)$ & - & & & $.59(.03)$ & 18.55 & $* * *$ \\
\hline Individual Knowledge of CR $\left(\beta_{7}\right)$ & - & & & $.10(.01)$ & 7.33 & *** \\
\hline \multicolumn{7}{|l|}{$\mathbf{C R} *$ Attributes Interactions $\left(\beta_{6}\right)$} \\
\hline CR* low clarity: & - & & & & & \\
\hline CR*24P true cinema & - & & & $-.02(.02)$ & -1.05 & \\
\hline CR* DTS 2.0+Digital out & - & & & $-.01(.02)$ & -.61 & \\
\hline CR* Backlight control & - & & & $.00(-)$ & - & \\
\hline $\mathrm{CR} *$ Dynamic range control & - & & & $-.02(.02)$ & -1.50 & \\
\hline \multicolumn{7}{|l|}{ CR* moderate clarity: } \\
\hline CR* Wall mountable & - & & & $.01(.02)$ & .48 & \\
\hline CR* Super slim design & - & & & $.00(.02)$ & .23 & \\
\hline CR* Large number of USBs & - & & & $.00(.02)$ & .16 & \\
\hline $\mathrm{CR} * \mathrm{PVR}$ & - & & & $.01(.02)$ & .90 & \\
\hline \multicolumn{7}{|l|}{ CR* high clarity: } \\
\hline $\mathrm{CR} *$ Screen Size & - & & & $.03(.01)$ & 2.59 & $* * *$ \\
\hline CR * Warranty & - & & & $.03(.01)$ & 2.33 & $* *$ \\
\hline CR * Price $\left(\beta_{5}\right)$ & - & & & $.03(.01)$ & 2.59 & $* * *$ \\
\hline Product Category Knowledge $\left(\beta_{8}\right)$ & & & & $-.07(.04)$ & & \\
\hline \multicolumn{7}{|l|}{ Model Statistics } \\
\hline Log likelihood & -12860.88 & & & -12347.74 & & \\
\hline Number of respondents & 395 & & & 395 & & \\
\hline McFadden Pseudo R ${ }^{2}$ & 0.072 & & & 0.108 & & \\
\hline
\end{tabular}

Note: standard errors recorded in parentheses, * significant at $10 \%, * *$ significant at $5 \%$, and *** significant at $1 \%$;

$\wedge$ recovered estimate of brand-effects relating to Toshiba obtained via relationship with two other effects coded brand-specific terms 
In Table 3, the estimates associated with the proposed model, Model 2, are presented. This model differs from Model 1 by the inclusion of a measure of corporate reputation - $C R_{i j}$, a standardized measure of reputation for each company-brand for each individual derived from the structural equation model (Appendix 1). As such, its inclusion partials out the overall aggregate brand name effects observed in Model 1 into the individual reputation effects for each company. A likelihood-ratio test confirms it as being a superior model to predict consumer choices $\left(\chi^{2}\right.$ $=1026.28 ; p<.001)$. The parameter estimate of $\beta_{4}$, capturing individual variation for reputation of these three companies, is positive and significant $(p<.001)$. As such, it indicates that individuals placed significant weight on corporate reputation when making choices among competing offerings. This result support Hypothesis 2.

In Table 3, we also introduce a set of terms that capture how individual level evaluations of corporate reputation may moderate the marginal utility of some product features, a key departure from previous models focusing on the general halo effects of corporate reputation. Hypothesis 3 focuses on the sensitivity that individuals have to the price of products being offered by a reputable company. The significant negative coefficient for $\beta_{4}$ confirms that respondents were significantly more likely to choose products that were lower in price as per H1b; however, the significant positive coefficient for $\beta_{5}$ in Model 3 confirms that individuals were significantly less (more) sensitive to the price of products offered by more (less) reputable companies $(p<.05)$, thereby providing support for Hypothesis 3.

In Model 2, we also introduce terms that capture how individual level evaluations of corporate reputation may change the preference for other product features. First, the results reveal that overall corporate reputation has no significant impact on moderating the marginal utility of any product feature with low or moderate product clarity. In contrast, changes in 
corporate reputation had a significant impact on effecting the evaluation of two product features with high clarity, namely, screen size and warranty $(p<.05)$. This implies that product features with high clarity have a higher marginal utility when offered by a company that is evaluated as having a better reputation relative to its competitors. As a result, these results confirm the predictions made in Hypothesis 4 that corporate reputation moderates the marginal utility of product features, but only for those features that are higher in value and more clearly understood by consumers.

Table 3 also introduces two individual-level variables capturing the role of knowledge in influencing product choice. The first variable captures a respondent's perceived knowledge of the company's reputation. We see that $\beta_{7}$ is significant $(p<.001)$ indicating that increases in overall knowledge of a company significantly increases the utility associated with products that it offers. This result provides support for Hypothesis 5 and the salience conceptualization of corporate reputation noted earlier.

The second knowledge-related variable is a five-item measure derived from Flynn and Goldstein (1999) to assess the subjective level of knowledge that a person has about the products under investigation. Respondents were asked to indicate how much they agreed or disagreed on seven-point Likert scales on items such as whether they “feel very knowledgeable about televisions” and whether among their circle of friends they are “one of the experts on television”. This measure was used to see if product knowledge influences the propensity to purchase any television in addition to the impact of the reputation of the company selling the product under consideration. As shown, the parameter capturing this effect, $\beta_{8}$, is not significant, thereby not providing support for Hypothesis 6. This indicates that intentions to purchase a new television did not vary across individuals because of differences in product category knowledge. One 
possible explanation for this is that the screening of respondents resulted in focusing on only qualified respondents who were already in the market for a new television; hence, intentions to purchase and/or category knowledge may have had less variation across this sample relative to a wider population of consumers as studied in other settings (e.g., Burke, 2013).

Finally, to further illustrate the effects of corporate reputation, we compute an estimate of the willingness to pay (WTP) for a television backed by a more reputable company. This estimate is calculated by assuming that two companies A and B are selling their products in this market at the average price in the choice experimental conditions of $\$ 1,749$. We then set one company's reputation at a level of one standard deviation above the other and calculate the price level at which A and B will have an equal probability of being chosen. That is, the WTP estimates are obtained by determining an equalization price such that the market shares of the two offerings are equal; a similar approach is used by Swait et al. (1993) in the context of brand equity. The results of these calculations are based on the estimates of the final model in Table 3 and reveal that if Company B is a standard deviation better in corporate reputation compared to the market average reputation it will have an equilibrium price of $\$ 1,901$. This average WTP implies that a one standard deviation improvement in corporate reputation is worth $\$ 152$; equivalent to a premium of $8.7 \%$. This estimate can be compared to the average WTP for various product features, as is shown in Figure 3. This illustrates the significant impact of improvements to corporate reputation on utility judgments and consumer choices relative to how various changes to the product offering are judged by consumers in our study. 


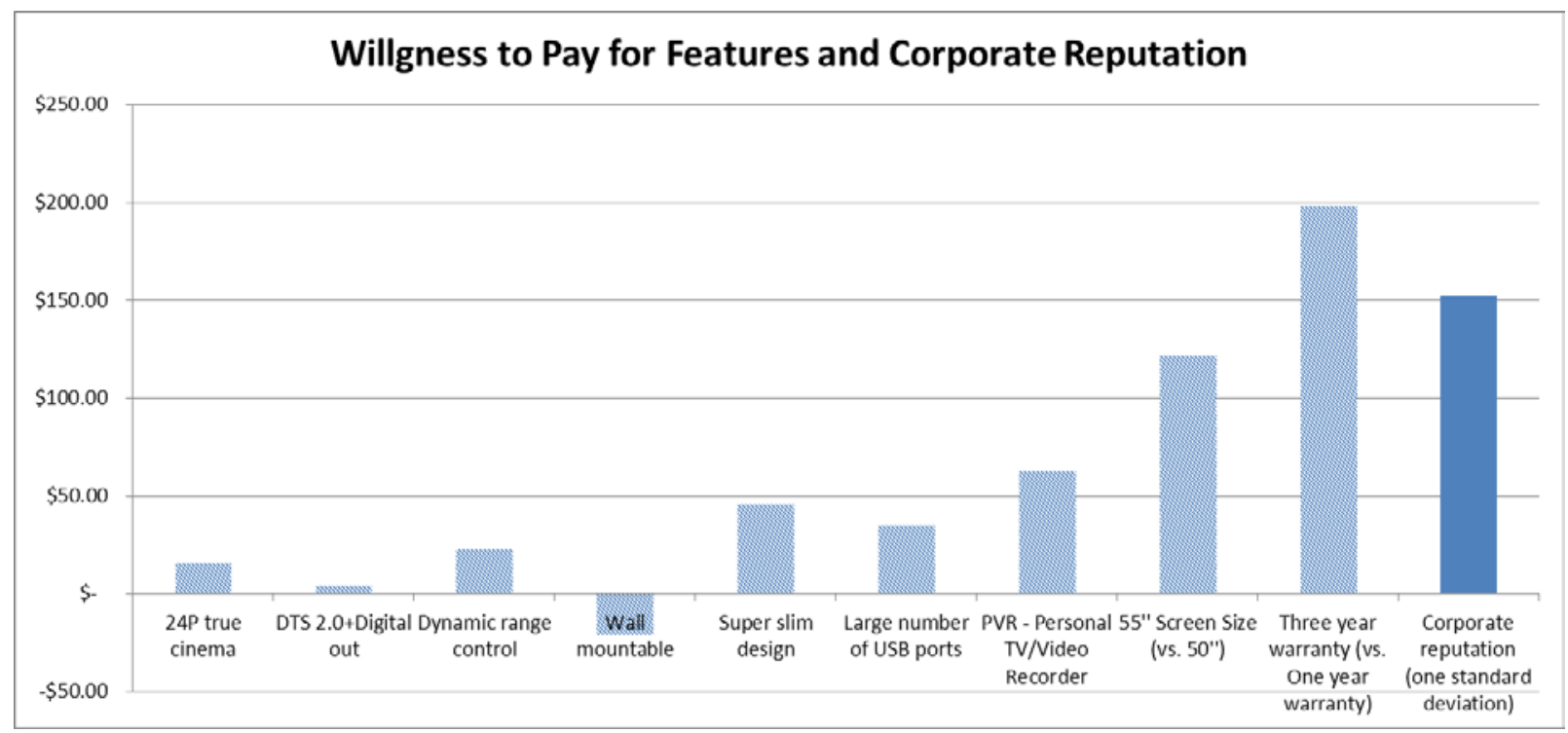

FIGURE 3: Willingness to Pay Estimates for Features and Corporate Reputation

One caveat to these figures, however, is that as Hypothesis 4 was supported, the WTP can vary for a product feature depending on the corporate reputation of the company offering the product. For example, in the case of screen size, consumers are willing to pay \$121 more for a television that is 55” over one that is 50”; this WTP amount increases to \$147 if the same offer is made by a company that is one standard deviation higher on the corporate reputation measure. Similarly, a consumer is willing to pay $\$ 198$ more for a television which comes with a three year warranty against an identical television offered with a one year warranty; this difference increases to $\$ 221$ when the same television is offered by a company one standard deviation higher with respect to its reputation. However, as was previously reported in relation to Hypothesis 4, the impact of corporate reputation on differences in WTP for product features is negligible for all other features included in the study. For example, the WTP for a Personal Video Recorder is \$63 regardless of the corporate reputation of the company offering the product with this feature. 


\section{Discussion}

The literature has shown that corporate reputation activities can provide valuable outcomes to multiple stakeholders (Arikan et al., 2016; Fombrun, 1996; Roper \& Davies, 2007). These outcomes have been considered across a number of dimensions, particularly with respect to financial performance and market valuation among investors (Qiu, Shaukat, \& Tharyan, 2016; Roberts \& Dowling, 2002; Tischer \& Hildebrandt, 2014) and an organization’s ability to attract and retain employees (Auger, Devinney, Dowling, Eckert, \& Lin, 2013; Greening \& Turban, 2000; Turker, 2009). In this research, we examined the role of corporate reputation in consumer choices, focusing on whether it enhances the overall and feature-specific utility of televisions offered in a competitive context. Our choice-based methodology indicates that holding a better reputation than one's direct competitors increases the overall utility of a product, it reduces price sensitivity, and it moderates the marginal utility of some important features of the product. Further, the reputation effect partially depends on how much the respondent knows about the company that is associated with the product they are considering to buy.

The findings indicate that companies with poorer reputations are less likely to have their products be chosen by consumers (as per a halo effect), but they are also likely to lose ground on several other product features. In the same manner in which corporate reputation can signal overall quality, the findings show that it is a useful signal of the quality of features; in turn, this alters preferences and influences how specific product features are evaluated (Boulding \& Kirmani, 1993). Specifically, we found that larger screen sized televisions were less likely to be chosen when offered by a company with a poorer corporate reputation. Similarly, we found that those companies with poorer reputations should be cautious in trying to compete against those 
with better reputations, especially by offering products with similar warranties. One strategic implication of this is that when companies are seeing their reputations damaged in one product category or at the organization level, the damage may extend to how some product features are evaluated in other categories.

The research, however, found no evidence for corporate reputation being a mechanism to enhance the marginal utility of product features that are trivial or poorly understood by consumers. It indicates that consumers have a limit to how much they are willing to pay for some product features even when the most reputable company is offering the feature. Instead it reinforces a view that marketers need to continue to offer product features that are important and understood rather than those that are meaningless or trivial (c.f., Broniarczyk \& Gershoff, 2003; Carpenter et al., 1994). The research also cautions against those with poorer reputations to compete against competitors with better reputations based on price. Instead, the findings suggest that those with poorer reputations need to continue to work on corporate branding activities as well as finding ways in which to offer more attractive products for consumers (Balmer, 2001; Balmer \& Gray, 2003; Yu Xie \& Boggs, 2006).

The findings in relation to individual knowledge about corporate reputation also demonstrate the importance of maintaining corporate visibility to further enhance the preference for a product. That is, efforts that promote a corporation's activities relating to the various facets of corporate reputation as measured in the RQ scale are all capable of enhancing reputational knowledge and value among consumers and are therefore warranted. The results speak to the suggestion that salience is an important component in driving reputation and subsequent competitive advantage (Fombrun \& van Riel, 2004; Lange, Lee, \& Dai, 2011). For marketers, these results reinforce their efforts in creating 'fame' around the company behind the brand and 
leveraging this salience via strategies like a branded house (Aaker, 2004; Aaker \&

Joachimsthaler, 2000). It also suggests merit in considering co-branding activities led by the company name (Rao, Qu, \& Ruekert, 1999).

An extension of this research would be to assess whether different aspects of corporate reputation lead to different product evaluations. For example, many studies of consumer reactions to companies focus on the social reputation of the company as a driver of engagement and product evaluation (e.g., Chernev \& Blair, 2015; Klein \& Dawar, 2004). However, in our analysis of the measurement properties of the RQ measure (see Appendix 1) we find that the correlation of each aspect of reputation with the overall measure to be so high that the analysis of any single aspect produces results that are indistinguishable from those reported in Table 3.

\section{Conclusions and Future Research}

The generalizability of the findings of our study is limited by a number of factors including the nature of our respondents (Australians), the product category studied (television), and the nature of our measure of corporate reputation (Dowling, 2016b). As such, whilst we found general support for each of the hypothesized effects consistent with an investigation of theory application (Calder, Phillips, \& Tybout, 1981), we also consider how the results might generalize across different settings and related boundary conditions.

As previously mentioned, there are various types of brand hierarchies used to create a link between a corporate and a product brand (Aaker \& Joachimsthaler, 2000). In this research we did not separate the effects of either because the chosen context was one in which the brand name and company name were identical. As such, it would be interesting to explore replications of the research in which the impact of the product brand and corporate brand could be considered 
separately. For example, it would be insightful to see the impact of the corporate reputation of General Motors in the context of consumer car purchases as separated from brands such as Buick, Cadillac, or Chevrolet, all of which fall under its ownership.

As we illustrate here, the reputation of a company can have a significant impact on product choice. Further, as the nature of the approach was to measure the relative impact of product features, price and corporate reputation, one strategic implication of these findings is that the building of corporate reputation is extremely important overall relative to distinguishing products solely on their product features. While this finding is consistent with many claims made by reputation practitioners, it is yet to be tested alongside the valuation of other product features. As such, the findings provide further motivation for companies to design and implement programs that enhance the reputation of their company in the eyes of consumers.

Our study also suggests that reputation enhancing activities will be most successful for consumers if they are also targeted at enhancing the valence of specific product features. Here, the good reputation of the company can deliver both a general effect and some feature-specific effects. For example, a company that seeks to be admired for its social responsibility should ensure that these activities also link directly to some product features. Few large companies that embark on broad CSR programs seem to take this extra step. Also, a company that seeks to be known for its innovation should ensure that this corporate characteristic is visible in the features of its products or in the customer interface design. For example, when Steve Jobs ran Apple many customers thought that the company was innovative and led by a charismatic rogue. Both these company characteristics supported the overall value proposition offered by Apple's various products and services. They could also be seen in many new features offered by the range of iProducts. Periodically Apple would make reference to its character and culture in its corporate 
advertising to advance the idea that the company behind the product mattered to what was its essential customer value proposition.

In the broader context, our results also suggest that there is merit in companies drawing attention to their corporate reputation. As discussed, companies such as Apple and $3 M$ are well known for doing so. A more extreme example of this is Cooper's beer (an Australian brand), who uses the corporate slogan "Our name is on the bottle, our reputation is inside it". At present, however, drawing attention to the reputation of the company that stands behind or beside the product is not a common communication strategy. One reason for this could be that companies are worried that a corporate crisis that degrades their reputation will then adversely affect their products (Greyser, 2009; Klein \& Dawar, 2004). However, our research suggests that those companies that are well regarded may be missing an opportunity to trade on one of their strongest market-based assets. Taking up this opportunity, however, comes with the responsibility to live up to their good name. 


\section{References}

Aaker, D. (2004). Leveraging the corporate brand. California Management Review, 46(3), 6-18.

Aaker, D. A., \& Joachimsthaler, E. (2000). The brand relationship spectrum. California Management Review, 42(4), 8-23.

Agarwal, J., Osiyevskyy, O., \& Feldman, P. M. (2015). Corporate reputation measurement: Alternative factor structures, nomological validity and organizational outcomes. Journal of Business Ethics, 130(2), 485-506.

Allen, F. (1984). Reputation and product quality. RAND Journal of Economics, 15(3), 311-327.

Arikan, E., Kantur, D., Maden, C., \& Telci, E. E.. (2016). Investigating the mediating role of corporate reputation on the relationship between corporate social responsibility and multiple stakeholder outcomes, Quality and Quantity, 50(1), 129-149.

Auger, P., Burke, P., Devinney, T. M., \& Louviere, J. J. (2003). What will consumers pay for social product features? Journal of Business Ethics, 42(3), 281-304.

Auger, P., Devinney, T. M., Dowling, G. R., Eckert, C., \& Lin, N. (2013). How much does a company’s reputation matter in recruiting? MIT Sloan Management Review, 54(3), 23.

Balmer, J.M. (1998). Corporate identity and the advent of corporate marketing. Journal of Marketing Management, 14(8), 963-996.

Balmer, J. M. (2001). Corporate identity, corporate branding and corporate marketing-Seeing through the fog. European Journal of Marketing, 35(3/4), 248-291.

Balmer, J. M., \& Gray, E. R. (2003). Corporate brands: What are they? What of them? European Journal of Marketing, 37(7/8), 972-997.

Barnett, M. L., \& Pollock, T. G. (2012). The Oxford handbook of corporate reputations. Oxford, UK: Oxford University Press. 
Ben-Akiva, M., \& Lerman, S.R. (1985). Discrete choice analysis (sixth ed.). London, England: The Massachusetts Institute of Technology Press.

Bergkvist, L., \& Rossiter, J. R. (2007). The predictive validity of multiple-item versus singleitem measures of the same constructs. Journal of Marketing Research, 44(2), 175-184.

Boulding, W., \& Kirmani, A. (1993). A consumer-side experimental examination of signaling theory: Do consumers perceive warranties as signals of quality?, Journal of Consumer Research, 20(1), 111-123.

Boulstridge, E., \& Carrigan, M. (2000). Do consumers really care about corporate responsibility? Highlighting the attitude - behaviour gap. Journal of Communication Management, 4(4), 355-368.

Brazell, J.D., Diener, C.G., Karniouchina, E., Moore, W.L., Severin, V., \& Uldry, P-F. (2006). The no-choice option and dual response choice designs. Marketing Letters, 17(4), 255-268. Broniarczyk, S.M., \& Gershoff, A.D. (2003). The reciprocal effects of brand equity and trivial attributes. Journal of Marketing Research, 40, 161-175.

Brown, T. J., \& Dacin, P. A. (1997). The company and the product: Corporate associations and consumer product responses. Journal of Marketing, 61(1), 68-84.

Burke, P. F. (2013). Seeking simplicity in complexity: The relative value of ease of use (EOU)based product differentiation. Journal of Product Innovation Management, 30(6), 1227-41.

Calder, B. J., Phillips, L. W., \& Tybout, A. M. (1981). Designing research for application. Journal of Consumer Research, 8(2), 197-207.

Carpenter, G. S., Glazer, R., \& Nakamoto, K. (1994). Meaningful brands from meaningless differentiation: The dependence on irrelevant attributes. Journal of Marketing Research, 31(3), 229-350. 
Caruana, A., Cohen, C., \& Krentler, K. A. (2006). Corporate reputation and shareholders’ intentions: An attitudinal perspective. Journal of Brand Management, 13(6), 429-440.

Chernev, A., \& Blair, S. (2015). Doing well by doing good: The benevolent halo of corporate social responsibility. Journal of Consumer Research, 41(6), 1412-1425.

Creyer, E.H. (1997). The influence of firm behaviour on purchase intention: Do consumers really care about business ethics? Journal of Consumer Marketing, 14(6), 421-432.

Dawar, N., \& Parker, P. (1994). Marketing universals: Consumers’ use of brand name, price, physical appearance and retailer reputation as signals of product quality. Journal of Marketing, 58(2), 81-95.

De Chernatony, L. (1999). Brand management through narrowing the gap between brand identity and brand reputation. Journal of Marketing Management, 15(1-2), 157-179.

De Pelsmacker, P., Driesen, L., \& Rayp, G. (2005). Do consumers care about ethics? Willingness to pay for fair-trade coffee. Journal of Consumer Affairs, 39(2), 363-385.

Devinney, T., Dowling, G. R., \& Perm-Ajchariyawong, N. (2008). The Financial Times business schools ranking: What quality is this signal of quality? European Management Review, 5, 195-208.

Dhar, Ravi (1997). Consumer preference for a no-choice option. Journal of Consumer Research, 24(2), 215-31.

Du, S., Bhattacharya, C.B., \& Sen, S. (2007). Convergence of interests-cultivating consumer trust through corporate social initiatives. Advances in Consumer Research, 34(6), 687.

Dowling, G. R. (2016a). Winning the Reputation Game. Boston, Mass: MIT Press.

Dowling, G. R. (2016b). Defining and measuring corporate reputations. European Management Review, 13(3), 207-223. 
Espeland, W. N., \& Sauder, M. (2007). Rankings and reactivity: How public measures recreate social worlds. American Journal of Sociology, 113, 1-40.

Erdem, T., \& Swait, J. (1998). Brand equity as a signaling phenomenon. Journal of Consumer Psychology, 7(2), 131-157.

Erdem, T., Swait, J., \& Louviere, J. J. (2002). The impact of brand credibility on consumer price sensitivity. International Journal of Research in Marketing, 19(1), 1-19.

Flynn, L. R., \& Goldstein, R. E. (1999). A short, reliable measure of subjective knowledge. Journal of Business Research, 46(1), 57-66.

Fombrun, C. J. (1996). Reputation. Realizing value from the corporate image. Harvard: Harvard Business School Press.

Fombrun, C. J., Gardberg, N., \& Sever, J. M. (2000). The reputation quotient: A multistakeholder measure of corporate reputation. Journal of Brand Management, 7(4), 241-254.

Fombrun, C. J., \& van Riel, C. B. M. (2004). Fame \& fortune. Upper Saddle River, NJ: FT Prentice Hall.

Gatti, L., Caruana, A., \& Snehota, I. (2012). The role of corporate social responsibility, perceived quality and corporate reputation on purchase intention: Implications for brand management. Journal of Brand Management, 20(1), 65-76.

Greening, D.W., \& Turban, D.B. (2000). Corporate social performance as a competitive advantage in attracting a quality workforce. Journal of Academy of Management, 40(3), $254-280$.

Greyser, S. A. (2009). Corporate brand reputation and brand crisis management. Management Decision, 47(4), 590-602.

Gürhan-Canli, Z., \& Batra, R. (2004). When corporate image affects product evaluations: The 
moderating role of perceived risk. Journal of Marketing Research, 41(2), 197-205.

Habel, J., Schons, L. M., Alavi, S., \& Wieseke, J. (2016). Warm glow or extra charge? The ambivalent effect of corporate social responsibility activities on customers' perceived price fairness. Journal of Marketing, 80(1), 84-105.

Helm, S. (2013). How corporate reputation affects customers’ reactions to price increases. Journal of Revenue and Pricing Management, 12(5), 402-415.

Hsee, C. K. (1996). The availability hypothesis: An explanation for preference reversals between joint and separate evaluations of alternatives. Organizational Behaviour and Human Decision Processes, 67(3), 247-257.

Hutchinson, J. W., Kamakura, W. A., \& Lynch Jr, J. G. (2000). Unobserved heterogeneity as an alternative explanation for "reversal" effects in behavioural research. Journal of Consumer Research, 27(3), 324-344.

Johnson, R., \& Orme, B. (2003). Getting the most from CBC. Sequim: Sawtooth Software Research Paper Series, Sawtooth Software.

Keh, H. T., \& Xie, Y. (2009). Corporate reputation and customer behavioural intentions: The role of trust, identification and commitment. Industrial Marketing Management, 38(7), 73242.

Keller, K. L. (2003). Brand synthesis: The multidimensionality of brand knowledge. Journal of Consumer Research, 29(4), 595-600.

Keller, K. L., \& Lehman, D. R. (2006). Brands and branding: Research findings and future priorities. Marketing Science, 25(6), 740-759.

Keller, K.L., \& Richey, K. (2006). The importance of corporate brand personality traits to a successful 21 $1^{\text {st }}$ century business. Journal of Brand Management, 14(1-2), 74-81. 
Klein, J., \& Dawar, N. (2004). Corporate social responsibility and consumers' attributions and brand evaluations in a product-harm crisis. International Journal of Research in Marketing, 21(3), 203-217.

Kocak, A., Abimbola, T., \& Özer, A. (2007). Consumer brand equity in a cross-cultural replication: An evaluation of a scale. Journal of Marketing Management, 23(1-2), 157-173.

Lacey, R., \& Kennett-Hensel, P.A. (2010). Longitudinal effects of corporate social responsibility on customer relationships. Journal of Business Ethics, 97(4), 581-597.

Lange, D., Lee, P. M., \& Dai, Y. (2011). Organizational reputation: A review. Journal of Management, 37(1), 153-184.

Louviere, J. J. (2013). Modeling single individuals: the journey from psych lab to the app store. Choice Modelling: The State of the Art and the State of Practice, 1-47.

Louviere, J. J., Hensher, D. A., \& Swait, J. D. (2000). Stated choice methods: Analysis and applications. Cambridge, UK: Cambridge University Press.

Louviere, J.J., \& Woodworth, G. (1983). Design and analysis of simulated consumer choice or allocation experiments: An approach based on aggregate data. Journal of Marketing Research, 20(4), 350-67.

Luce, R. (1959). Individual choice behaviour: A theoretical analysis. New York: Wiley. MacCallum, R. C., Browne, M. W., \& Sugawara, H. M. (1996). Power analysis and determination of sample size for covariance structure modeling. Psychological Methods, 1(2), 130-149.

McFadden, D. (1974). Conditional logit analysis of qualitative choice behaviour, in P. Zarembka (Ed.), Frontiers in Econometrics, 105-142.

McFadden, D. (1986). The choice theory approach to market research. Marketing Science, 5(4), 
275-297.

March, J. G. (1978). Bounded rationality, ambiguity, and the engineering of choice. The Bell Journal of Economics, 9(2), 587-608.

Mohr, L. A., \& Webb, D. J. (2005). The effects of corporate social responsibility and price on consumer responses. Journal of Consumer Affairs, 39(1), 121-147.

Napoli, J., Dickinson-Delaporte, S., \& Beverland, M. B. (2016). The brand authenticity continuum: Strategic approaches for building value. Journal of Marketing Management, 32, 1201-29.

Nguyen, N., \& Leblanc, G. (2001). Corporate image and corporate reputation in consumers' retention decisions in services. Journal of Retailing and Consumer Services, 8(4), 227-236.

Page, G., \& Fearn, H. (2005). Corporate reputation: What do consumers really care about? Journal of Advertising Research, 45(3), 305-313.

Ponzi, L., Fombrun, C., \& Gardberg, N. (2011). RepTrak ${ }^{\mathrm{TM}}$ Pulse: Conceptualizing and validating a short-form measure of corporate reputation. Corporate Reputation Review, 14, 15-35.

Qiu, Y., Shaukat, A., \& Tharyan, R. (2016). Environmental and social disclosures: Link with corporate financial performance. The British Accounting Review, 48(1), 102-116.

Rao, A. R., Qu, L., \& Ruekert, R. W. (1999). Signaling unobservable product quality through a brand ally. Journal of Marketing Research, 36(2), 258-268.

Ratchford, B. T. (2001). The economics of consumer knowledge, Journal of Consumer Research, 27(4), 397-411.

Rindova, V. P., \& Martins, L. L. (2012). Show me the money: A multidimensional perspective on reputation as an intangible asset. In M. L. Barnett and T. G. Pollock (eds.), The Oxford 
Handbook of Corporate Reputations (Oxford, Oxford University Press), 16-33.

Roberts, P. W., \& Dowling, G. R. (2002). Reputation and sustained superior financial performance. Strategic Management Journal, 23(12), 1077-1093.

Roper, S., \& Davies, G. (2007). The corporate brand: Dealing with multiple stakeholders. Journal of Marketing Management, 23, 75-90.

Rose, J. M., \& Bliemer, M. C. (2013). Sample size requirements for stated choice experiments. Transportation, 40(5), 1021-1041.

Schlegelmilch, B.B., \& Pollach, I. (2005). The perils and opportunities of communicating corporate ethics. Journal of Marketing Management, 21(3-4), 267-290.

Schultz, M., Hatch, M. J., \& Adams, N. (2012). Managing corporate reputation through corporate branding. In M. L. Barnett and T. G. Pollock (eds.), The Oxford Handbook of Corporate Reputations (Oxford, Oxford University Press), 420-445.

Shapiro, C. (1982). Consumer information, product quality, and seller reputation. The Bell Journal of Economics, 13(1), 20-35.

Shapiro, C. (1983). Premiums for high quality products as returns to reputations. The Quarterly Journal of Economics, 98(4), 659-679.

Soberman, D. A. (2003). Simultaneous signaling and screening with warranties. Journal of Marketing Research, 40(2), 176-192.

Srivoravilai, N., Melewar, T. C., Martin, J. L., \&Yannopoulou, N. (2011). Value marketing through corporate reputation: An empirical investigation of Thai hospitals. Journal of Marketing Management, 27(3-4), 243-268.

Swait, J., Erdem, T., Louviere, J., \& Dubelaar, C. (1993). The equalization price: A measure of consumer-perceived brand equity. International Journal of Research in Marketing, 10(1), 
23-45.

Thurstone, L.L. (1927). A law of comparative judgment. Psychological Review, 34 (4), 273-86. Tischer, S., \& Hildebrandt, L. (2014). Linking corporate reputation and shareholder value using the publication of reputation rankings. Journal of Business Research, 67(5), 1007-1017.

Train, K. E. (2009). Discrete choice methods with simulation. Cambridge University Press.

Turker, D. (2009). How corporate social responsibility influences organizational commitment. Journal of Business Ethics, 89(2), 189-204.

Walsh, G., Dinnie, K., \& Wiedmann, K.P. (2006). How do corporate reputation and customer satisfaction impact customer defection? A study of private energy customers in Germany. Journal of Services Marketing, 20(6), 412-420.

Walsh, G., Mitchell, V. W., Jackson, P. R., \& Beatty, S. E. (2009). Examining the antecedents and consequences of corporate reputation: A customer perspective. British Journal of Management, 20(2), 187-203.

Yu Xie, H., \& Boggs, D. J. (2006). Corporate branding versus product branding in emerging markets: A conceptual framework. Marketing Intelligence \& Planning, 24(4), 347-364. 


\section{Appendix 1: Reputation Quotient Measurement}

The Reputation Quotient (RQ) was developed to be a multi-stakeholder measure of corporate reputation (Fombrun, Gardberg, \& Sever, 2000). Thus, it is suitable for use with a group of people from a wide range of backgrounds, in this case a variety of potential consumers.

Conceptually the construct of reputation defined by Fombrun, noted in the paper, and measured by the RQ is a multi-attribute evaluation of a company. Agarwal, Osiyevskyy and Feldman (2015, p. 488) suggest that it is best modelled and measured as a second-order reflective construct. Hence, we performed a structural equation model analysis (SEM) on RQ as shown in Figure 4.

The instrument includes 20 items that are construed to form into six latent constructs of corporate reputation. In the following example, the measurement model shows the six latent constructs and their relative items to measure the corporate reputation of Sony, as we did in the formal survey. For a different company, the word "Sony" can be replaced with a different company name.

\section{Construct 1: Emotional Appeal (AP)}

$\mathrm{X} 1$ : I have a good feeling about Sony

$\mathrm{X} 2$ : I admire and respect Sony

X3: I trust Sony

Construct 2: Product and Services (PS)

X4: Sony stands behind its products and services

X5: Sony develops innovative products and services

X6: Sony offers high quality products and services

X7: Sony offers products and services that are a good value for money

Construct 3: Vision and Leadership (LD)

X8: Sony has excellent leadership

X9: Sony has a clear vision for its future

X10: Sony recognizes and takes advantage of market opportunities

Construct 4: Workplace Environment (WE)

$\mathrm{X} 11$ : Sony is well-managed

$\mathrm{X} 12$ : Sony looks like a good company to work for

$\mathrm{X} 13$ : Sony looks like a company that would have good employees

Construct 5: Social and Environment Responsibility (SER)

$\mathrm{X} 14$ : Sony supports good causes 
X15: Sony is an environmentally responsible company

X16: Sony maintains high standards in the way it treats people

Construct 6: Financial Performance (FP)

X17: Sony has a strong record of profitability

$\mathrm{X} 18$ : Sony looks like a low risk investment

X19: Sony tends to outperform its competitors

X20: Sony looks like a company with strong prospects for future growth

We first tested RQ with 116 pilot respondents. Each respondent was asked to nominate the companies that sold televisions they believed had the best and worst corporate reputation. We then piped in these company names for each respondent to rate on the $20 \mathrm{RQ}$ statements. They were rated using 7-point Likert scales labelled "1 strongly disagree" to "7 strongly agree”. This ensured that respondents were answering questions about a particular company.

To test the structure of the instrument we used structural equation modelling (SEM) to recover the six latent constructs. The results of the SEM in Table 1 show an acceptable level of statistical fit for the key indicators RMSEA and CFI, even with a small sample of 116 respondents (e.g., MacCallum, Browne, \& Sugawara, 1996). Figure 1 shows the theoretical model using the pilot data, demonstrating strong and sound relationships between the 20 observed variables, six latent constructs and the top level latent construct of CR. Also, reliability results show the theoretical measurement model has a high level of reliability, with Cronbach alpha at 0.98 for "Emotional Appeal", 0.96 for "Product Services", 0.96 for "Vision and Leadership”, 0.98 for “Workplace Environment”, 0.96 for “Social and Environment Responsibility” and 0.97 for Financial Performance” respectively.

In the formal study, we asked a sample of 395 people who intended purchase a television set to rate the reputations of Sony, Panasonic and Toshiba using the 20 RQ items on 7-point Likert scales. Similar to how we analysed the pilot data we combined the rating data for all three companies and performed the same SEM analysis. The SEM results shown in Figure 5 were 
similar to those obtained in the pilot study with slightly better statistical fits (e.g., RMSEA is 0.062, which improved from the pilot results of 0.073).

For each respondent we had three predicted reputation scores, one for each company. These scores were standardized to allow better comparison and model interpretation, such as for the willingness-to-pay estimates reported in the paper. We then embedded these scores into the choice data by matching each reputation score with its corresponding brand.

To further validate our approach to measuring corporate reputation we also asked respondents to rate the reputation of Sony, Panasonic and Toshiba on a 10-point scale where the answer options were "very poor” to "very good”. Here Sony received an average rating of M = $7.15(\mathrm{SD}=1.81)$, Panasonic $\mathrm{M}=6.78(\mathrm{SD}=1.76)$ and Toshiba $\mathrm{M}=6.17(\mathrm{SD}=1.8)$. Bergkvist and Rossiter (2007) suggest that in many cases single-item measures are just as reliable as their multi-item counterparts. The correlation between these self-stated overall measures of corporate reputation and the corresponding latent corporate reputation measures is 0.76 overall. This further indicates our measures adequately capture reputations of the companies investigated.

Table 5: Structural Equation Model Fit Statistics - Pilot and Formal Studies

\begin{tabular}{lcc}
\hline \multicolumn{1}{c}{ Fit Statistics } & $\begin{array}{c}\text { Pilot Study } \\
(\mathbf{n}=\mathbf{1 1 6})\end{array}$ & $\begin{array}{c}\text { Formal Study } \\
\text { (n = 395) }\end{array}$ \\
\hline $\begin{array}{l}\text { Population Error } \\
\text { RMSEA (Root mean squared error of } \\
\text { approximation) }\end{array}$ & 0.073 & 0.062 \\
Information Criteria & & \\
AIC (Akaike's information criterion) & 9754.01 & 45996.69 \\
BIC (Bayesian information criterion) & 10095.24 & 46473.97 \\
Baseline Comparison & & \\
CFI (Comparative fit index) & 0.98 & 0.98 \\
TLI (Tucker-Lewis index) & 0.97 & 0.98 \\
Size of Residuals & & \\
SRMR (Standardized root mean squared residual) & 0.01 & 0.02 \\
CD (Coefficient of determination) & 0.99 & 0.99 \\
\hline
\end{tabular}




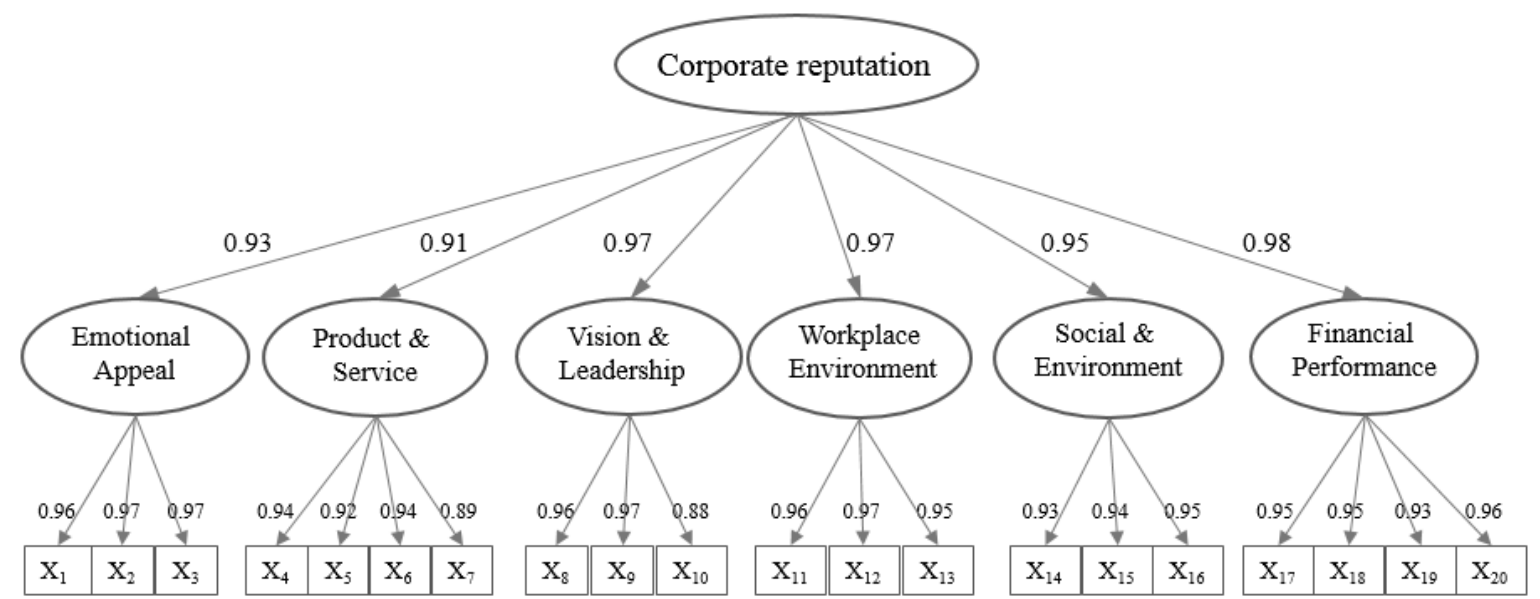

Figure 4: Relationships in the SEM model using ratings data on self-selected companies with the best and worst corporate reputation $(n=116)$

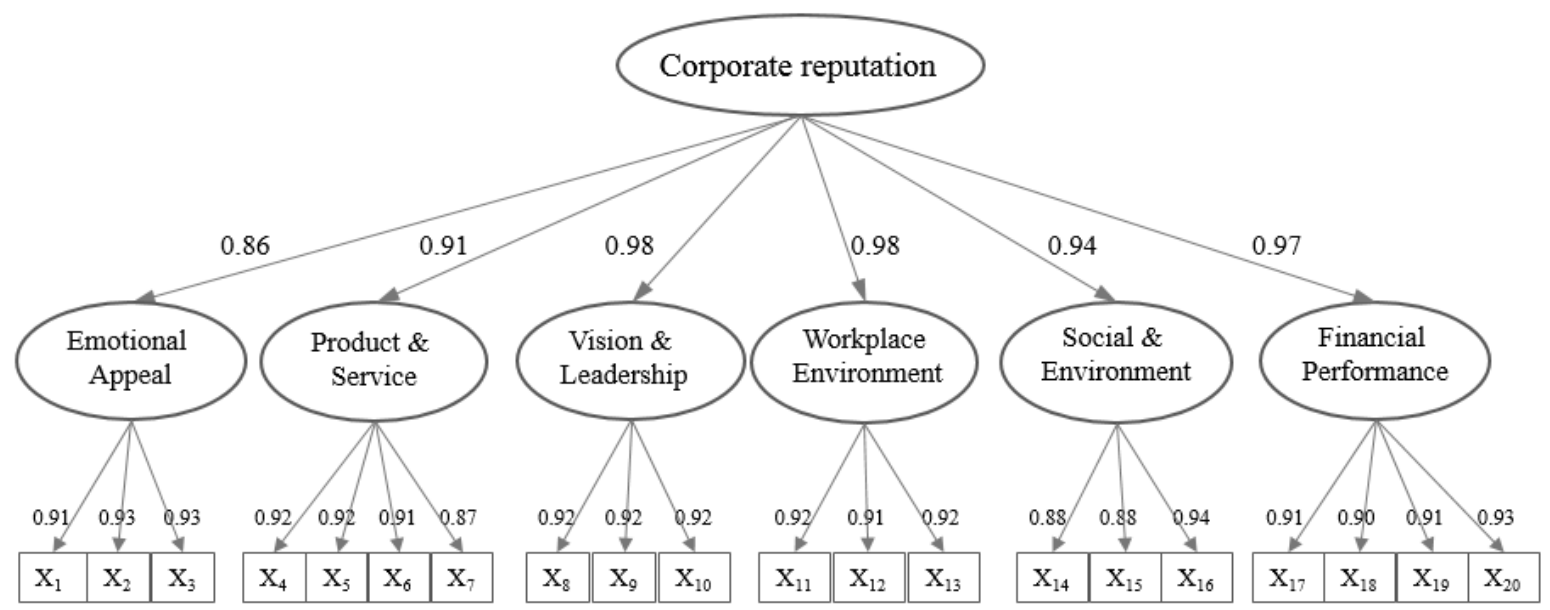

Figure 5: Relationships in the SEM model using ratings data on the three brands Sony,

Panasonic and Toshiba $(\mathrm{n}=395)$ 